\title{
Tuna Bulgar Hanlı̆̆ı'nın Başkentleri: Pliska (680) ve Preslav (893)
}

\author{
The Capitals of the First Bulgarian Kingdom: Pliska (680) and Preslav (893)
}

\begin{abstract}
Meltem AKINCI *
Öz: VII. yüzyılda Büyük Bulgar Hanlığı’nın çökmesi ile Bulgarların bir kısmı Asparuh önderliğinde Karadeniz düzlüklerinden hareketle Balkanlara göç etmiştir. $\mathrm{Bu}$ göç neticesinde Tuna boylarında devletleşen Bulgarlar, Doğu Avrupa'da iki büyük başkentin mimarı olmayı başarmıștır. Bu başkentlerden ilki Aşağı Tuna’nın güney sınırında Asparuh tarafından ilk olarak karargâh şeklinde belirlenen Pliska, diğeri ise IX. yüzyılda Bulgar topraklarında Hristiyanlığı şahlandıran Boris tarafından ilan edilen Preslav'dır. Preslav, her ne kadar Hristiyanlığın temelinin atıldığı bir başkent olarak göze çarpsa da, şehrin farklı yerleşim bölgelerinde konargöçer kültür emarelerine rastlanılmaktadır. Bulgar yerleşimlerinin yapısal özelliklerinin aydınlatılması yazılı kaynaklardan daha çok, arkeolojik araştırmalar neticesinde gerçekleşmiştir. Bu araştırmalar sonucunda ekonomik canlılığa vurgu yapan ticari materyaller, zanaat mamulleri, tarımsal araç-gereçler, büyük ölçekli yerleşimler, idari, dini ve askeri yapılar, alt yapı unsurları vb. ortaya çıkartılmıştır. Tüm bu öğeler hem konargöçer şehircilik kültürünün hem de Orta Çağ feodal şehircilik anlayışının girift bir manzarasını sunmaktadır. Konargöçer Bulgarlar, göç ettikleri bölgeye, kendi Salt-Mayat kültür unsurlarını da getirmişler; böylece yerleşik halkların da dâhil olmasıyla Doğu Avrupa'da farklı bir şehircilik anlayışı ortaya çıkarmışlardır.
\end{abstract}

Anahtar sözcükler: Tuna Bulgar Hanlığı, Pliska, Preslav, Şehircilik

Abstract: With the collapse of the Great Bulgarian Khanate in the VII ${ }^{\text {th }}$ century, some of the Bulgarians under the leadership of Asparuh emigrated from the Black Sea plains to the Balkans. As a result of this immigration, Bulgarians became nationalized on the Danube and became the architects of two major capitals in Eastern Europe. The first of these capitals was Pliska, which was designated as the first headquarters by Asparuh on the southern border of the Lower Danube, and the other was Preslav, declared by Boris, who celebrated Christianity in the Bulgarian territory in the $\mathrm{IX}^{\text {th }}$ century. Although Preslav stands out as a capital in which Christianity was first laid, there are signs of nomadic culture in different settlements of the city. The clarification of the structural features of these Bulgarian settlements has been achieved through archaeological research rather than from written sources. As a result of these studies, commercial materials, craft products, agricultural tools, large-scale settlements, administrative, religious and military structures and infrastructure elements that emphasize economic viability were shown. All these elements provide an detailed view both of the nomadic urban culture and medieval feudal urbanism. Nomadic Bulgarians brought their own Salt-Mayat cultural elements into the region they migrated to; thus, with the inclusion of settled peoples, a different understanding of urbanism has emerged in Eastern Europe.

Keywords: First Bulgarian Kingdom, Pliska, Preslav, Urbanism

\footnotetext{
* Ph.D., Akdeniz Üniversitesi, Sosyal Bilimler Enstitüsü, Tarih ABD, Antalya. mltm.akinci@hotmail.com, https://orcid.org/0000-0003-0807-1113
} 


\section{Giriş}

VII. yüzyılın ilk yarısında doğuda Göktürk Kağanlığı'nın dağılması, batıda ise Avarların güç kaybetmesiyle Kafkas düzlüklerinde yaşayan Bulgar boyları (Başta Utigur ve Kutrigur olmak üzere Ogur boylarının, Hun bakiyeleriyle birleşimi sonucunda Bulgar etnonimi ortaya çıkmıştır. Ahmetbeyoğlu 2010, 1-19), Kubrat Han liderliğinde bir araya gelerek yeni bir devlet vücuda getirmiştir. 630 yılında kurulan Büyük Bulgar Hanlığı, hâkim olduğu Kuzey Kafkasya'da ne yazık ki çok fazla hüküm sürememiş, kurucu lideri Kubrat'ın 665 yılında ölümüyle dağılma sürecine girmiştir. Bulgarlar hakkında en teferruatlı bilgiyi veren Doğu Roma kaynaklarından biri olan Nikephoros'un Tarihi (Br. Hist. 35) Kubrat'1n ölümünden sonraki tabloyu şu şekilde sunmaktadır:

"Kobrat (Kubrat) öldüğ̈̈nde, karşılıklı dostlukları sayesinde, hâkim olduklarl yerleri koruyabilmeleri için, hiçbir koşul altında bölünmemelerini önerdiği beş oğul bıraktı. Fakat onlar babalarının tavsiyelerini çok önemsemediler ve kısa bir süre sonra her biri halklarından kendi payın alarak ayrıldı. Baianos (Batbayan) adındaki en büyük oğul, babasının buyruğuna uyarak, atalarının topraklarında bugüne değin kalmıştır. Kotragos (Kotrag) ismindeki ikinci oğul, Tanais Nehri'ni (Don) geçmiş ve birincisinin karşısında kalmış; dördüncü Istros Nehri'ni (Tuna) geçmiş ve Avarlar hâkimiyetindeki Pannonia'ya yerleşmiştir. Beşincisi, Ravenna'nın Pentapolis'inde (Ravenna ve Ankona arası) yerleşti ve Romalılara bağlandl. Asparuh ismindeki üçüncü kardeş, Danapris ve Danastris nehirlerini (Dnyeper ve Dnyester) geçti ve Istros yakınlarına yerleşti. Burada düşman tarafindan zor ve zapt edilemez olan uygun bir yerleşim yeri buldu: buranın önü güvenilirdi çünkü geçit vermez ve bataklıktır, arkası ise erişilemez kayalıklarla çevrilidir".

Nikephoros'un aktarmış olduğu haberde geçen beşinci oğul, uluslararası literatürde Birinci Bulgar Krallığı'nın yani Tuna Bulgar Hanlığı'nın kurucusudur. Asparuh Han'ın 670 dolaylarında Tuna'nın kuzeyinde ilerleyişi Doğu Roma'yı kuşkulandırır ve Bulgarlara karşı atağa geçmesine sebebiyet verir. Fakat Doğu Roma ordusu Bulgarların ilerleyişini durduramaz. (Niceph. Br. Hist. 36-37) Asparuh önderliğindeki Bulgarlar, nehri geçip Dobruca ve Deliorman'1 zapt ederek Filibe-Burgaz çizgisinin kuzeyine yerleşirler. Birçok Slav kavmini de birliğine dâhil eden Bulgarların bu ilerleyişi, Doğu Roma'nın Bulgarları fiili olarak tanımasına neden olur. Doğu Roma ile 681 yılında imzalanan barış anlaşması ile Tuna Bulgar Hanlığı resmi olarak kurulur (Karatay 2018b, 276). Peki, Tuna Bulgarlarının, Onglos (Doğu Roma kaynaklarında bu şekilde geçiyor) yani Güney Besarabya civarına yerleşmesinin sebebi nedir?

Devlet'in, Tuna boylarında vücuda gelmesinden ötürü Tuna Bulgarları ismini alan Kubrat'ın torunları için Tuna Nehri'nin önemi büyüktür. Devletin geleceği ve gelişimi için ilk mevkilenen arazi sadece Tuna Bulgarları için değil, birçok Türk kavminin geleceği için de (Örneğin İtil Bulgarları da İtil Nehri kıyısını yurt tutmuş; ilk etapta siyasi, ticari ve zanaat alanında ilerleyip gelişmesini çoğunlukla bu nehre borçlu olmuştur.) belirleyici olmuştur. Tarihi süreç içerisinde milletlerin, coğrafi unsurları bir avantaj ya da dezavantaj olarak görmesi gerçekten siyasi kaderlerinin tayininde oldukça önemli rol oynamıştır. Bu hususta Türkler, suyolları başta olmak üzere doğal unsurları bir avantaj olarak değerlendirerek, askeri stratejilerde ve ekonomik planlamalarda bu hususlardan yararlanmasını bilmiştir.

Birçok kavim tarih boyunca Aşağı Tuna'nın kuzey kıyısında yaşamayı tercih etmiştir. Çünkü Tuna onların koruyuculuğunu üstlenmiştir. Bununla birlikte yukarıda da bahsetmiş olduğumuz gibi avantaj olarak gördükleri bu konum vasıtasıyla, kışın donmuş Tuna üzerinden Doğu Roma İmparatorluğu'na saldırabilmişlerdir. Çoğu Doğu Roma kaynağı Romalıların, 
Tuna'nın kuzeyli halklarıyla savaştıklarını kaydetmiştir (Theophanes Chronographia 357). Tarihsel bağlamda da yeterli donanması olmadan Tuna Bulgarlarının Tuna'nın her iki kıyısındaki alana hâkim olmayı nasıl başardığını anlamak, fiziki coğrafyaya hükmetme yetenekleriyle alakalı olsa gerektir. Bulgarlar Tuna'yı geçtikten sonra, devletlerine kuzey Tuna bölgesini dâhil edememiş olsa da, nehrin sı ̆̆ yerlerine inşa ettikleri kalelerin varlığı askeri açıdan çok önemli olmuştur (Corbu 2013, 89). Fakat günümüzdeki Tuna ile tarihsel Tuna arasında farkl11ıklar bulunmaktadır. $\mathrm{Bu}$ durum doğal olarak yerleşim alanlarında değişimler yaşanmasına sebep olmuştur. Farklılığın sebebi ise çok farklı nedenlere dayanmakla birlikte Tuna'nın doğal yapısı, Karadeniz seviyesinin yükselmesi ya da insan müdahaleleri bunlardan başlıca olanlarıdır. Ama özellikle bu bölgedeki insan müdahalesi, örneğin büyük nehir yataklarına set çekilmesi, nehir boyunca endüstriyel binaların ya da barajların yapılması, demiryolları ve yolların suyollarına müdahalesi değişimin ana kaynaklarındandır. Yani insan müdahaleleri sebebiyle Tuna'nın tarihsel yapısı bozulmuştur. Bu sebeple Corbu'ya (2013, 85-88) göre tarihçilerin mevcut Tuna haritasından yola çıkarak, eski yerleşimlerin yerini tespit etmeleri oldukça zordur.

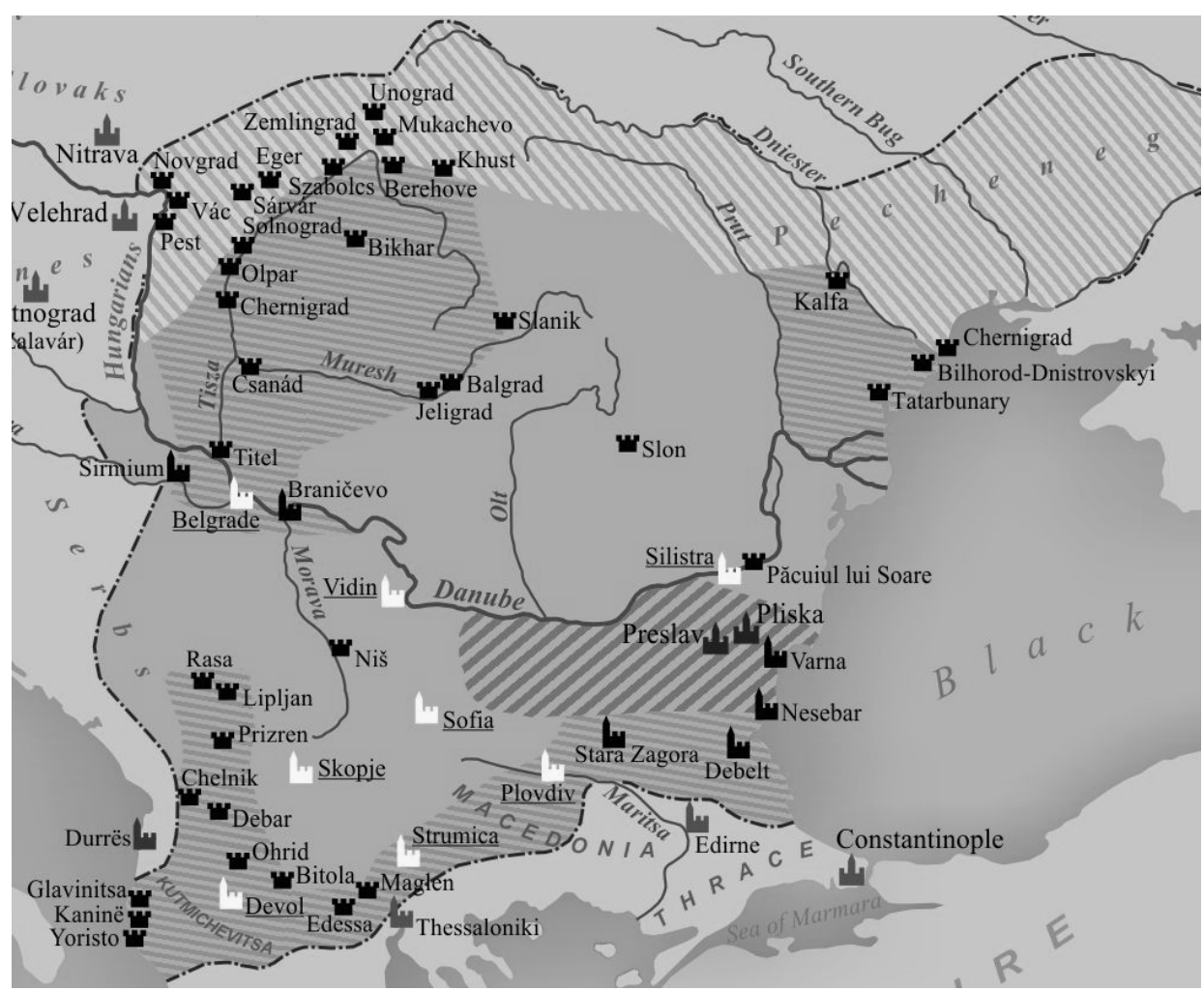

Fig. 1. Pliska ve Preslav'ın konumları (Henning 2007)

VII. yüzyılın son çeyreğinden X. yüzyılın ilk yarısına kadar sınırlarını oldukça genişleten ve güçlenen Tuna Bulgar Hanlığı'nın hâkim olduğu sahanın varlığının tayini bugün bile tam olarak netlik kazanmamıștır. Öyle ki IX. yüzyılın Karpat Havzası'nda Tuna Bulgar Hanlığı'nın mevcudiyeti ve hâla bu bölgenin genişlemesi yanıt arayan sorulardandır. XIX. yüzyıldan bu yana bu soru, birçok yanıt ile formüle edilse de, genel olarak üç farklı yaklaşım ortaya çıkmıștır. Bu üç farklı yaklaşımı ise M. Takacs kendi açıklamalarını dâhil ederek özetlemiștir. İlk olarak yalın olarak nitelendirilebilecek yaklaşım S. Runciman tarafından 1930'da formüle edilmiștir. Buna göre Tuna Bulgarlarının kuzey sınırı, Sırbistan'ın en batıdaki Bulgar kalesi olarak Sırbistan'ın başkenti Belgrad ile Tuna Nehri hattına koyulmuștur. Takacs'a göre Runchiman, Bulgarların Karpat Havzası'na yayılmasına değinmediğinden ihtiyatlı bir yaklaşımın temsilcisi olarak görülebilir. Bu hususla ilgili birçok noktaya da vurgu yapılabilmektedir; örneğin Orta Çağ 
Macaristan'ında yazılan Latince metinlerde Belgrad'ın yer adı, "Alba Bulgariae" olarak görünmektedir. İkinci yaklaşım, Çek kökenli bilim adamı K. Jireçek tarafından formüle edilmiştir. Jireçek “iyimser yaklaşım”'ında, 800 civarında Avar Kağanlığı'nın dağılmasında Tuna Bulgar Hanlığı'nın belirleyici bir rol oynamasına dikkat çekmiştir. Ona göre Bulgar gücü Sirem'de (Tuna ve Sava nehirleri arasında, Büyük Macaristan Ovası'nın güneyinin bir kısmı), Tuna, Tisa ve Maroş nehirleri arasında uzanan Büyük Ova'nın güneydoğusunda, Banat'ta (Günümüzde Macaristan, Romanya ve Sırbistan sınırları içerisinde kalan bölge) bulunmaktaydı. Macar tarihçiler genellikle bu iyimser yaklaşımı benimsemişlerdir. Aynı şekilde Doğu Roma tarihini yazan G. Ostrogorsky de, IX. yüzyılda İlk Bulgar Devleti'nin (Tuna) yalnızca Sirem ve Banat'ta olduğunu belirterek bu görüşe katılmıştır. Tuna Bulgar Hanlığı'nın Karpat Havzası'na yayılmasıyla ilgili üçüncü yaklaşım I. Dünya Savaşı'ndan sonraki yıllarda hem Macaristan hem de Bulgaristan'da oluşmuştur. Bu yaklaşımı sahiplenenler ise Bulgaristan'da V. N. Zlatarski (1970), Macaristan'da ise J. Melich olmuştur. İki bilim insanı da, Bulgar gücünün IX. yüzyıldaki genişlemesini ana hatlarıyla belirlemek için yer isimlerinin dilbilimsel analizlerini kullanmıştır. Bu yaklaşıma göre Pest, Nograd, Zemplen yer isimlerinin Bulgarca özellikleri taşıması sebebiyle, IX. yüzyılda Bulgar Hanlığı'nın sınırları bu şehirleri birbirlerini bağlayan hat üzerinde belirlenmelidir. Yani bu durum Karpat Havzası topraklarının çoğunluğunun, yani Tuna Nehri'nin doğusundaki tüm bölgeleri, Büyük Ova'nın tamamını, aynı zamanda Transilvanya'nın da dâhil olacağı anlamına gelmektedir. Fakat bu yaklaşım M. Takacs'a göre çok da gerçekçi durmamaktadır. Zira coğrafi isimlerin ortaya çıkışının kesin olarak kronolojik zaman ölçeği, dil bilimsel yöntemlerle tanımlanamamaktadır. Bununla birlikte coğrafi yer isimlerinin Bulgar kökenli oluşu, göç, ticaret vb. gibi birçok faktörle açıklanabilir (Takacs mekân tayini ile ilgili yaklaşımları açıkladıktan sonra, kendisine göre bu yaklaşımların analizini de yapmıştır. 2016, 502-506).

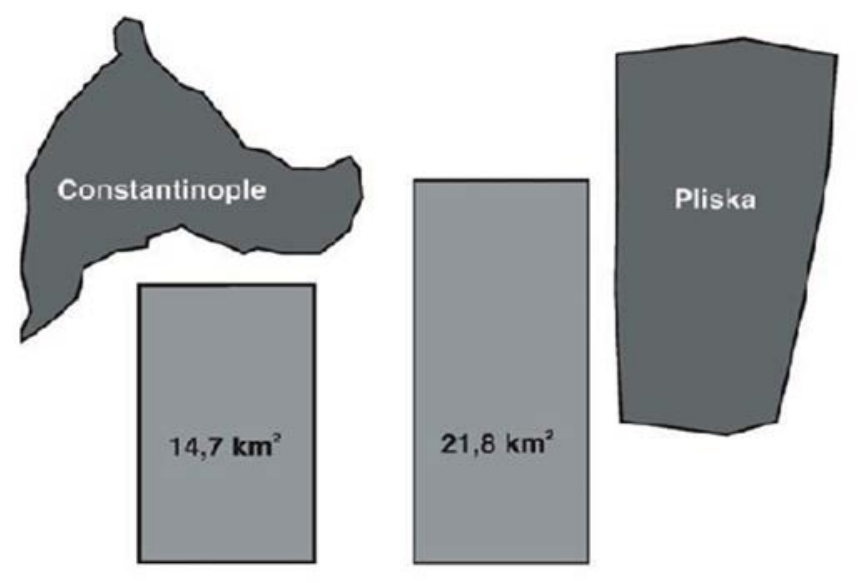

Fig. 2. Pliska ve Konstantinopolis'in karşılaştırılması (Henning 2007)

Tuna Bulgar Hanlığı'nın sınırları tartışmalı bir konu olsa da, Bulgarların hükmettikleri süre boyunca hâkim oldukları sahaya farklılık kazandırmış oldukları herkes tarafından kabul edilmektedir. Bu yenilikler sadece din, politika ve askeri çerçevede gerçekleşmemiş tarım, zanaat ve mimari gibi alanlarda da kendi kültürlerini yeni yurtlarına aktarmışlardır. Konumuz itibariyle şehircilik olgusu ise, özellikle Orta Çağ için derinlemesine incelenmesi gereken bir hususu oluşturmaktadır. Üstelik sınırlandırmayı Orta Çağ şehirciliği ile sınırlamak da yeterli olmamakta, Orta Çağ'da Doğu Avrupa şehirciliği demek, bir nebze de olsa işimizi kolaylaştırmaktadır. Bununla birlikte bölgede hâkim olan Roma kültürünün altında, diğer halkların sosyo-kültürel gelişimi kaynaklara pek fazla yansımamıştır. Aynı şekilde Bulgarlar gibi konargöçer kavimlerin 
şehircilik anlayışı ile yerleşik ahalinin şehircilik anlayışının (nasıl askeri, siyasi ya da hukuki alanlarda da farklı1ıklar taşıyorsa) aynı doğrultuda olması beklenemez. Bu hususta birkaç noktaya değinmek faydalı olacaktır. Bilindiği gibi Hazar Hakanlığı uzun y1llar çok farklı etnik kavmi VII. yüzyıldan itibaren devlet çatısı altında birleştirip, ortak bir kültür yaratmayı başarmıştır. Bu siyasi yapılanma içerisinde uzun yıllar Kafkaslar ve Karadeniz sahası içerisinde yaşayan Bulgar boyları Hazarların Don ve Azak civarında kendilerini mağlup etmeleri ile göç etmek zorunda kalmıştır. Bir kısmı böylece İtil Bulgarlarını bir kısmı da Tuna Bulgarlarını oluşturmuştur. Göçebe Bulgarlar, göç ettikleri bölgeye, kendi Salt-Mayat kültür (Don Nehri ve Azak Denizi civarında, özellikle VIII-X. asırlara tarihlenen ve Hazar, Bulgar gibi Türk boylar1nın da içerisinde yer aldığı karma kültüre verilen addır. Topsakal 2018, 28-29) unsurlarını (metalürji, çömlekçilik, mezar vb.) da getirmişlerdir. Genellikle kaynaklar Eski Türkler için göçebe tabirini kullanmakla birlikte bu sınırlama oldukça hatalıdır. Köken olarak konargöçer kültüre sahip olan Türkler doğudan batıya doğru olan göçlerinde, keşfettikleri yeni yurtlarında farklı kültürler ile tanışarak hayat standartlarında bazı değişimler yaşamıştır. Örneğin Hazar Hakanlığı içerisinde hem göçebe hem de yerleşik unsurları bir arada barındırmaktadır. Bu sebeple yerleşik hayata aşina olan Türk kavimleri üç farklı tarzda şehir yerleşimi gerçekleştirmiştir: taşınabilir, yarı sabit ve sabit. Tamamen göçebe olan kavimlerin şehirleşme adına çok fazla adım atamadığ Bulgarlarında bu durumun tersi yaşanmaktadır. Yazılı kaynaklara göre, Bulgar ve diğer Türk hükümdarlarının en önemli egemenlik alametlerinden birini, onların karargâhı oluşturmaktadır. Türkçede yurt anlamına gelen bu kavram, literatürde devlet, ülke kavramlarını karşılamaktadır. Hükümdarın karargâh merkezinde onun çadırı yani yurt bulunmaktadır. Bu yurt aynı zamanda, karargâhın tüm askeri ve siyasi kararların alındığı merkezidir (Nadırova 2010, 20-22). Yerleşik ve şehir kültürünün gelişimiyle birlikte, hükümdar karargâhı bir şehir ve sarayla yer değiştirmiştir (Ögel 1991, 85-86). Seferler için artık ordunun toplanma yeri tahsis edilmeye başlanmıştır. Bulgarların egemenlik sistemi ülkenin ortasında yukarıda da bahsi geçtiği gibi eşmerkezli daire şeklindedir: yani karargâh, karargâh merkezi/yurt, taht (Nadırova 2010, 23).

İlk etapta tahsis edilen şehrin daha çok askeri kamp niteliğinde olması ve sonrasındaki gelişiminin tam olarak bir şehir hüviyetinde olup olmadığı da farklı bir tartışma hususudur. Araştırmacılar ilk Bulgar şehirlerini devlet ikametgâhları avullarla (Tuna Bulgar müstahkem mevkilerine avul/agul denmektedir) ile birlikte tanımlamaktadır. Özellikle Pliska'nın IX. yüzyılın sonuna kadar tipik bir Orta Çağ kenti olmamasını, zanaat olanaklarının eksikliğine bağlanmaktadır. IX. yüzyılın sonuna gelindiğinde başkent bir yerleşim yerini almış olsa da X. yüzyılda hala tipik bir feodal şehir haline gelmemiştir. R. Raşeyev'e göre, Bulgaristan'daki şehirler müstahkem bir Han konutu avul şeklindedir (Raşeyev 2006, 58). Birçok şehir Han ikametgâhı ile doludur (Pliska, Preslav, Krum, Kabiyuk) Bununla birlikte zanaatkârlar şehir kalesinin dışında yoğunlaşmış ve alışverişi burada gerçekleştirerek banliyölerin oluşumunu sağlamıştır. Mimari planlama yapısı, nüfus yoğunluğu Tuna Bulgarları da dâhil olmak üzere antikçağdan beri bir şehrin ana özellikleri arasındadır. Bu sebeple G. Atanasov'a göre bir Bulgar şehri çevre yerleşimlerinden daha yoğun bir nüfusa, tahkimat yapılarına, dini tapınağa, üretim ve ticari faaliyetlere sahip olmalıdır. Fakat bazı araştırmacılara göre bu da yeterli olmayabilir. Örneğin Krum Han köyündeki bir avul, bu özelliklerin hepsine sahiptir fakat çoğunlukla şehir olarak adlandırılmamaktadır. Müstahkem bir ikametgâhın varlığı, bir şehri tanımlamak için yeterli değildir. Bazı araştırmacılar ise banliyölerin ya da bahsi geçen tahkimli alanların varlı̆̆ını kentsel karakterizasyon için yeterli görmektedir. Her iki görüşte de ortak olan unsur herhalde kentsel gelişimde zanaat, üretim ve ticaretin yadsınamaz rolüdür (Atanasov 2013, 206-208). Bunun yanı sıra G. Atanasov Orta Çă̆ şehirlerinin (her ne kadar askeri, idari, dini, sosyal yapılara sahip olsa da) müstahkem merkezlerinde halkın yaşamamış olmasına ve sınırlı erişime dikkat çekmektedir. Pliska, Preslav, Krum Han gibi yerlerin dışındaki çoğu yerleşimde temsili 
saraylar, dini tapınaklar gibi yerleşim kompleksleri, altyapı, garnizon hatta avullar bulunmaktadır; tüm bunların da ötesinde zanaatkâr ve tüccarların dâhil olduğu belirli bir nüfus kitlesi bulunmaktadır. Yani Atanasov’a göre bir şehrin görünümü sadece saraylardan, soyluların evlerinden ya da büyük katedrallerden oluşamaz; şehir nüfusu olmadan şehir tanımlaması yapmak doğru değildir. Bu sebeple ona göre Kuzeydoğu Bulgaristan'da çoğu merkezi şehir olarak tanımlamak yerine bunlara temsili ikametgâhlar demek daha doğru olacaktır. Sonuç olarak Atasanov, Orta Çağ'dan kalma bir Bulgar şehri için farklı kriterler oluşturmuştur. Fakat Doğu Avrupa ve Batı Avrupa Orta Çağ şehirlerinin kıyaslamaya tabi tutulması biraz hatalı olacaktır. Zira batıda şekillenen feodal yapılanma ile yerel üretim hızlanmış, ticaretin de tetikleyici etkisiyle kentsel gelişimin temelleri atılmıştır. Bununla birlikte Atasanov'un her ne kadar Bulgar vakayinamelerinde Asparuh'un Pliska şehrini kurmasından bahseden ifadelere yer vermiş olsa da bunları kayda değer bulmamasının sebebi bir nebze tatmin edici durmaktadır. İfade ettiğine göre XI. yüzyıla kadar şehir terimine vurgu yapan bir Bulgar kaynağı bulunmamaktadır. Öyle ki Preslav'ın inşa süreciyle çağdaş bir kaynak, şehir yerine saray ve ikametgâh/konut ifadelerini kullanmıştır. Yine IX. yüzyılın ortalarında Bavyera coğrafyacısı Bulgar topraklarında beş adet kalenin bulunduğunu, şehirlerin ise olmadığını kaydetmiştir (2013, 210-211).

Bizim ele alacağımız Pliska ve Preslav şehirleri özellikle başkent olmaları hasebiyle dikkat çekmektedir. Bununla birlikte Atasanov'un bahsetmiş olduğu üzere, bu tarz yerleşimleri şehir olarak kabul etmemek de çok kesin bir yargı olarak göze çarpmaktadır. Zira, bir yerleşimin şehir olarak sayılması için birçok kriterin gerekliliği (nüfus, ekonomik işlevsellik, korunaklı yapılar vb.) bilinse de, Orta Çağ için bu durum kavimlere göre değişiklik gösterebilmektedir. Yani, yukarıda bahsettiğimiz gibi Doğu Avrupa'da Doğu Roma menşeli bir şehir ile Bulgar ya da Hazar menşeli bir şehrin standart özelliklere sahip olması beklenemez. Zira şöyle de bir husus vardır ki Balkan dağlarının kuzeyi ve Tuna Nehri'nin güneyi, VII. yüzyılın sonunda Bulgar Devleti'nin merkezi olmadan önce, çoğunlukla kentsel niteliklerden mahrum kalmıştır. Kentsel yaşamın bu durağanlığ arkeolojik buluntularla da doğrulanmıştır. Başkent Pliska ve daha sonrasındaki Preslav hariç, Erken Doğu Roma-Geç Roma dönemine ait kalelerin birkaç kalıntısı, sınırları koruyan kaleler, Balkan dağları geçişinde Bulgarlar tarafından kullanılmıştır. Bulgaristan bölgesinde eski şehir alanlarının yeniden işgal edildiğine dair ilk göstergeler, başkent Pliska ve sonraki başkent Preslav'da IX. yüzyılın sonları ve X. yüzyılın başlarında para sirkülâsyonuna dair olan arkeolojik kaynaklardır. 865 yılında Bulgar topraklarının Hristiyanlaşması ve eski piskoposluk merkezlerinin yeniden kurulması şehirciliğe hizmet etmiştir. Zira eski piskoposluk merkezleri, eski şehir alanlarına daha fazla insanı çekmekle birlikte, ekonomik ve idari değişimlere de sebebiyet vermiştir. Fakat başkent Pliska ve Preslav bu hususta istisna oluşturmaktadırlar. Her iki şehir de yöneticilerin müstahkem mevkileri olmakla birlikte, seçkinlerin ihtiyaçlarına hizmet eden ekonomik işlevlere sahip olmuşlardır. Tuna Bulgar Hanlığı'nın ekonomisi, kendi kendine yetme, karşılıklılık ve doğal değişim ya da idare edilen ticaret tarafindan belirlenmiştir. Çoğunlukla altın olmak üzere para, düzenli piyasa faaliyetlerinin değil de diplomasinin ve devletin uluslararası ticaretinin aracı olmuştur. Daha sonrasında Doğu Roma İmparatorluğu'nun siyasal bir uzantısı haline gelen Bulgar toprakları, doğal olarak daha gelişmiş bir para ekonomisine de katılmıştır (Murdzhev 2008, 134- 135).

\section{Pliska}

665 y1lında Tuna'ya sefer yapan Asparuh Han, fethettiği toprakları korumuş ve yeni bir başkent tesis etmiştir. Bu durum XI. yüzyıla ait anonim bir Bulgar vakayinamesinde de geçmektedir: "Çar İspor (Asparuh)...Tuna'dan denize kadar büyük lider olmuş ve Pliska şehrini kurmuştur". Bulgarların cüzi bir ordu ile Doğu Roma topraklarını işgali, imparatorluk tarafından reaksiyona sebep olmuştur. Araplar Konstantinopolis üzerine gerçekleştirdiği kuşatmayı kaldırır kaldırmaz, 680 yılı başlarında imparator IV. Konstantinos'un bulunduğu imparatorluk ordusu Oglos’ta 
Bulgarları kuşatmış, fakat birkaç gün sonra mağlup olmuştur. Onları kovalayan Asparuh Han, Așağı Tuna'nın güney sınırına varmış; Hemus dağları (Bugün Balkan dağları/Stara Planina) ve Odessa, Marsianopolis gibi büyük Doğu Roma şehirlerine yakın olan bu mevkii yeni karargâhı için ele geçirmiştir. Bu karargâh ise "Pliska" adını almıştır (Raşayev 2006, 48). 680'li yıllarda birçok Slav'ı bünyesi altına almayı başaran Asparuh, Doğu Roma ile barış antlaşması yaparak bölgede bulunan tüm Slav ve Bulgarların hükümdarı olmuş; Tuna Bulgar Hanlığı'nı kurmuştur. Devletin başkenti ise yukarıda adı geçen karargâh Pliska olmuştur (Simakova 2007, 2). Karatay'a göre Bulgar Hanlığı'nın kurulması ve Doğu Roma tarafından resmen kabul edilmesi, İstanbul'un bu kadar yakınında bulunan geniş bir arazinin Doğu Roma'nın elinden çıkıp düşman bir devletin merkezi haline gelmesi açısından önemlidir (2018a, 140).

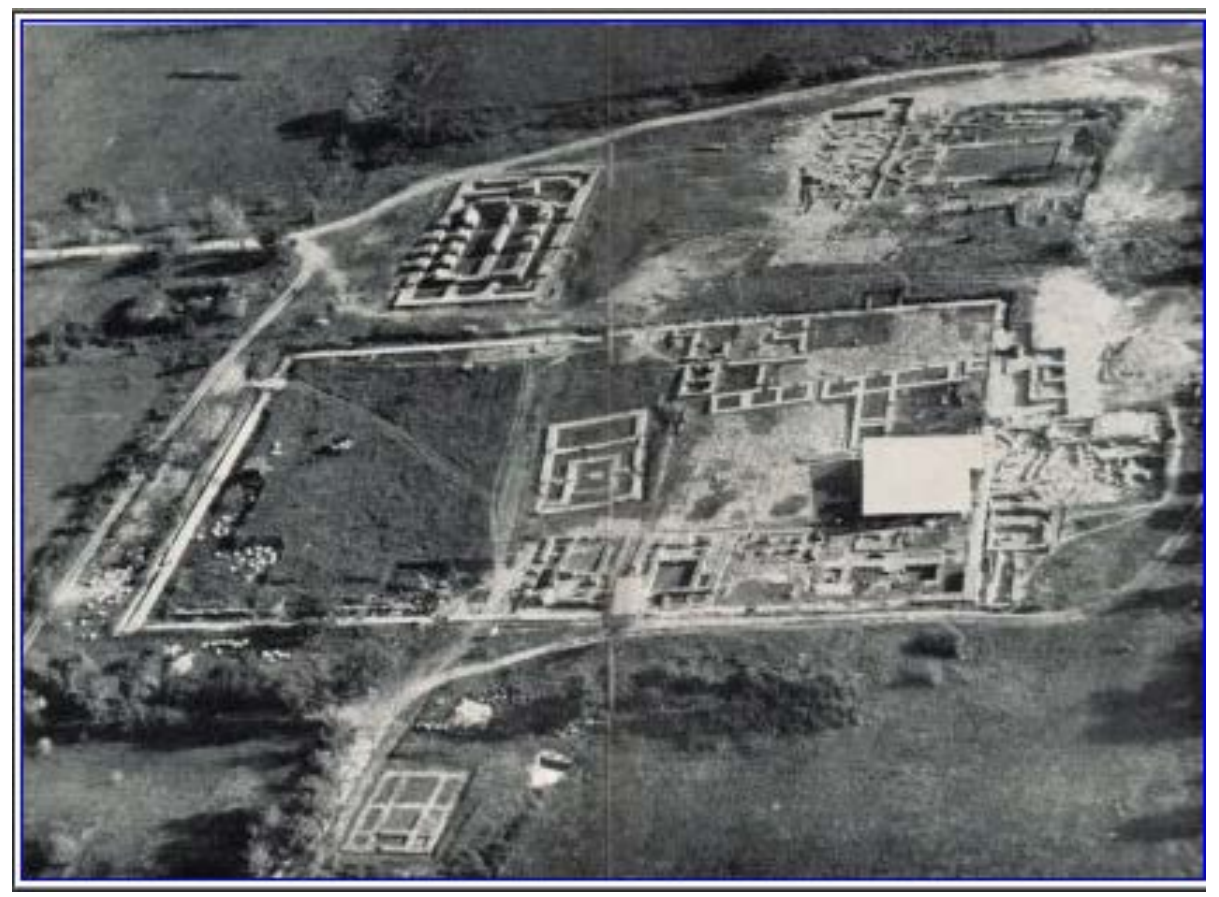

Fig. 3. Pliska'da hanların ikametgah kompleksi

(http://www.kroraina.com/pliska/pl_2.html)

1898 yılında Çek kökenli bir bilim adamı ve öğretmen olan Karel Şkorpil ilk kez Erken Orta Çağ' da Bulgaristan'ın ilk başkenti hipotezini yayımlamıştır. Onun görüşüne göre Pliska olan bu şehir, Bulgar yöneticilerin yazılı kaynaklarda ilk kez bahsedilmesinden yaklaşık 200 yıl önce var olmuştur. Bu durum Bulgaristan'ın ulusal kimliğinde çok derin bir şekilde kök salmıştır. Pliska şehri ile ilgili olarak, Şkorpil 1899 y1lında Rus Arkeoloji Enstitüsü tarafından finanse edilen ve yürütülen kazıların başladığı Kuzeydoğu Bulgaristan'da Aboba köyünün yakınlarında büyük bir tahkimat noktası olduğunu iddia etmiştir. Onun başlatmış olduğu bu tartışma, Bulgaristan'da diğer tarihçiler tarafından da oldukça dikkat çekici bulunmuş ve tartışmanın devamına sebep olmuştur (Uspenskiy 1905, 7). Şkorpil'in iddiaları herhangi bir ideolojiden ziyade tamamen bilimsel verilere dayanmıştır. Tuna Nehri'nin güneyine yerleştikten sonra Asparuh liderliği altında Bulgarlar tarafından kurulan bu tarz kalıcı bir başkent çıkarımını yapabilmek için kullanılacak kaynaklar ise oldukça yetersiz olmuştur. Aslında "Pliska", Doğu Roma kaynaklarında Preslav'dan daha sonra bile, yani I. Tzimiskes'in Bulgaristan'a karşı 971 yıllarındaki başarılı saldırısıyla bağlantılı bir yer adı olarak ortaya çıkmaktadır. Doğu Roma kaynakları ve Hellence yazılmış Bulgar taş yazıtları tahkimatlı bir dizi avludan, saraydan ya da evden, yapılar topluluğundan bahsetmektedir. Bunlar çoğunlukla ismi konulmamış ve bu sebeple yerini belirlemenin zor olduğu (Tiros Nehri'ndeki avul ve Durotorum'un dışındakiler 
hariç) yapılardan oluşmaktadır. Bu siteler muhtemelen hükümdar tarafından değişimli olarak kullanılmış ve ona ait olmuştur. Doğu Roma kaynakları belirli bir bölgeyi adlandırmak için topografik bir ifadeyle (nehir, yer, civar) bağlantılı olarak kampos kelimesini kullanmayı tercih ettiklerinden dolayı, Kağan Omurtag'ın 822 yıllı sütununda kampos, Pliska bölgesi ya da Pliska alanı olarak çevrilmiş olması muhtemel "Pl(i)ska" olarak adlandırılmıştır. Burası Doğu Roma kaynaklarında, Bulgarların takviye edilmiş bir ordugâhı ya da Balkanları işgal eden kendi ordusunun bir askeri kampının belirlenmesi için kullanılmamıştır (Henning \& Eyub 2007, 425426). Fakat Uspenskiy ve Şkorpil $(1905,545)$ ve Zlatarski'nin $(1970,580)$ kampos kelimesini yukarıda geçen anlamıla tercüme etmesinden beri, başkent ya da büyük bir ordugâh şehri izlenimi yaygınlaşmıştır (Henning \& Eyub 2007, 425-426).

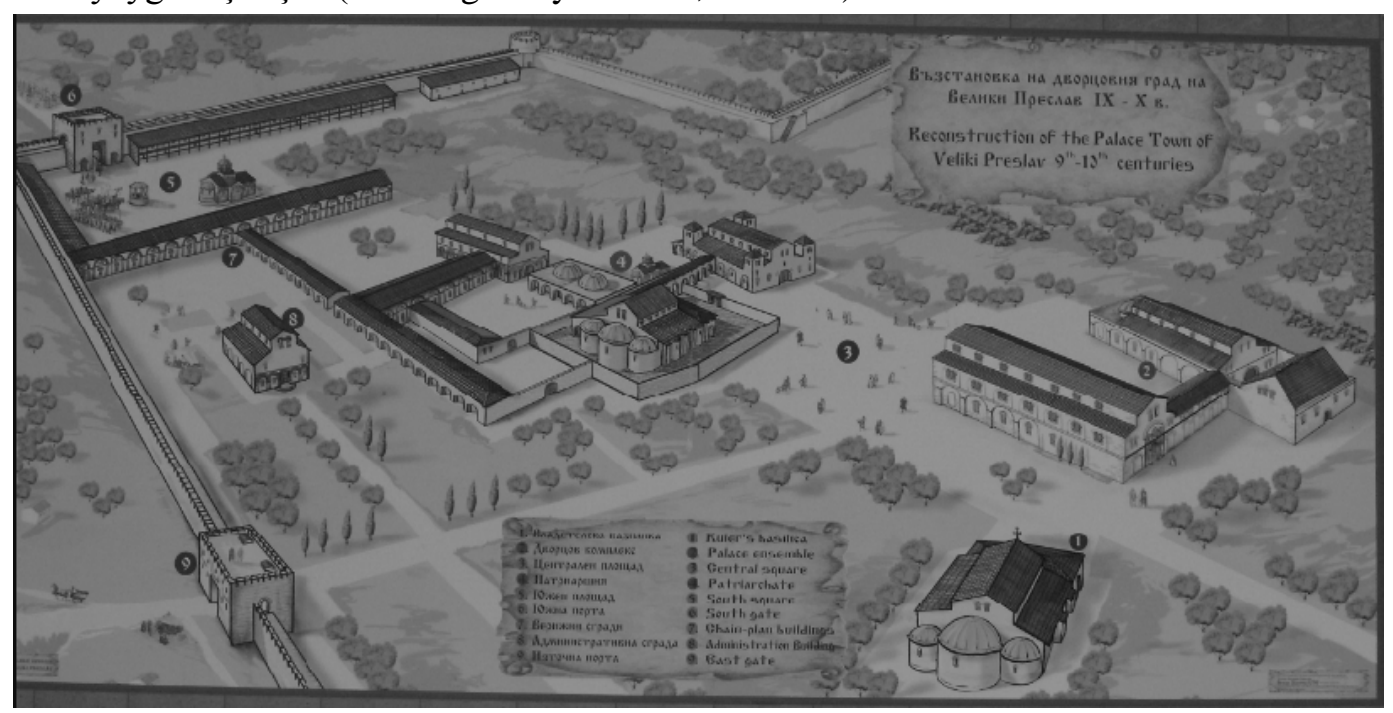

Fig. 4. X-XII. yüzyılda Preslav’ın muhtemel görüntüsü (Henning 2007)

1905 yılında Şumnu bölgesinde keşfedilen ünlü Hellence sütun yazıtına göre, 815'ten 831'e kadar Erken Orta Çağ'da Bulgar topraklarının hükümdarı olan Omurtag Han, 822 yılında Pliska kamposdan gelmiş (veya orada) ve Tisa Nehri'nde bir saray inşa etmiştir. Bu yazılı kaynaklarda Pliska'ya yapılan ilk referanstır. Aynı yazıttan, Omurtag Han'ın sarayının müstahkem bir yap1 olduğu, Hellenlerin ve Slavların Bulgarlara karşı olduğu ve hükümdarın Tisa Nehri üzerinde bir köprü inşa ettiği anlaşılabilmektedir. Müstahkem saray dört sütun ve iki bronz aslanla süslenmiştir (Zlatarski 1970, 575-580). Pliska kamposun Pliska havzasına topografik bir karakterizasyon olarak mı, yoksa Pliska adında askeri bir kampa mı atfedildiği konusu yukarıda da bahsi geçtiği gibi uzun süre tartışma konusu olmuştur. Topografik birimlerin alan/saha anlamına gelen tanımına çağdaş Doğu Roma literatüründe de rastlanabilmektedir. Bu sebeple Pliska sahası, Pliska havzası ya da Pliska ovası mümkün olabilecek çevirilerden birkaçı olabilmektedir. Her durumda, Pliska ovasındaki yönetim merkezi, 811 yılında I. Nikephoros'un yaptığı sald1rıda, koruma seviyesi, kalitesi ya da yeniden yapılanma aşaması ne olursa olsun bir çeşit savunma görevi üstlenmiş olmalıdır. Bu nedenle çeviri sorunu, Pliska ovasındaki yöneticinin tahkimat niteliği ile çok az bir şekilde ilintilidir. Aynı şey, Omurtag'ın sütunda belirtilen müstahkem sarayı için de geçerlidir. Bu çeviriyi yapan kişinin avulu (aul) Hellence anlamına saray olarak tercüme edilmesini tercih edip etmediğinden veya bu Hellence kelimenin $\dot{\eta} \alpha \hat{\jmath} \lambda \dot{\eta}$ (Liddle \& Scott 1883, 248) aul olarak adlandırılmasında kullanılmış olup olmamasından bağımsızdır: bu bozkır-göçebe veya ağırlıklı olarak güçlendirilmiş kavim veya yönetici merkezdir ( Henning \& Balabanov 2007, 434). 


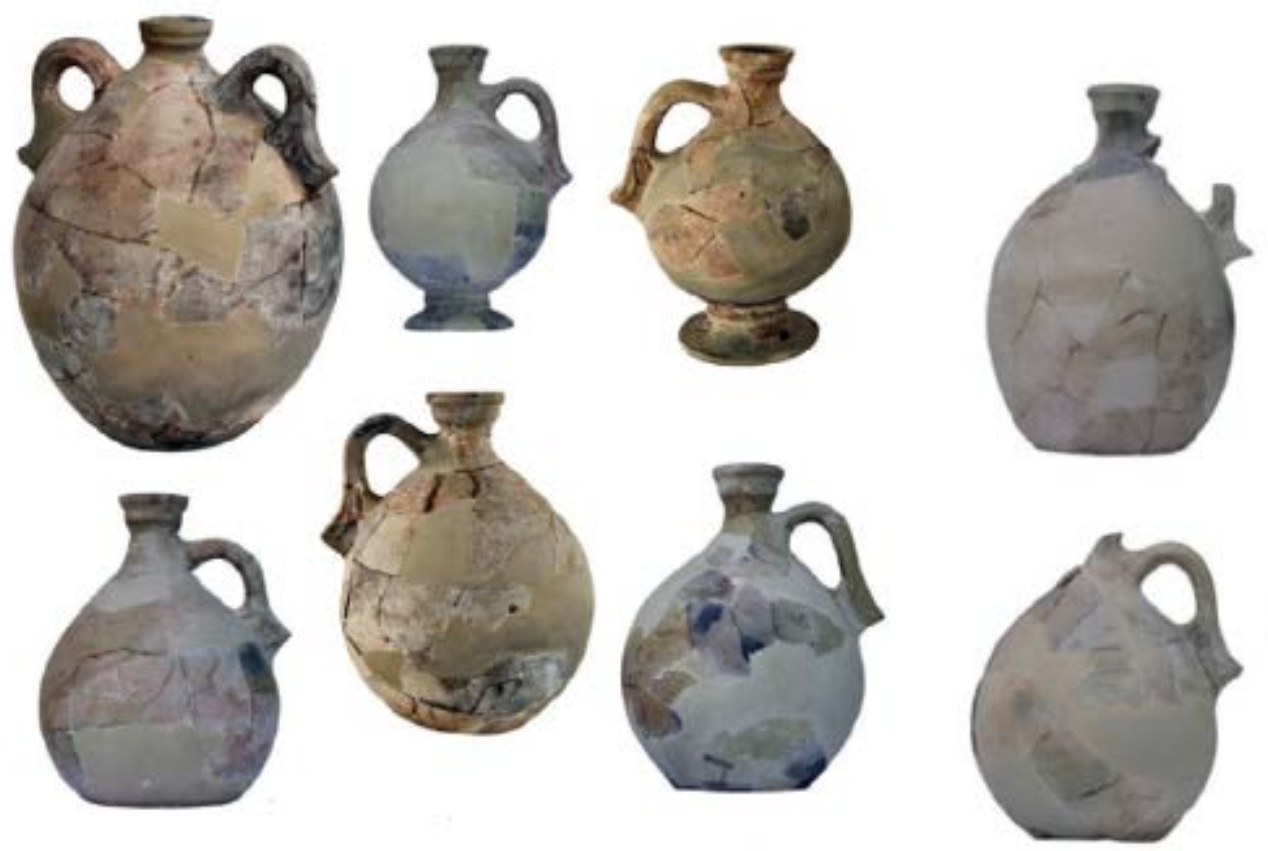

Fig. 5. Pliska'da bulunan çömlekler IX-X. yüzyıl (Grigorov 2013, 122)

VIII. yüzyılda Asparuh önderliğinde devletleşen Tuna Bulgarlarının ilk merkezi olan Pliska'nın Asparuh, Krum, Omurtag ve Balamir tarafindan hem başkent hem de karargâh olarak kullanılmıș olduğu tarihçiler ve arkeologlar tarafından onaylanmaktadır. Bu șehrin çevresinde bulunan Hellence kitabeler, Asparuh dıșında bahsi geçen hükümdarların ikamesiyle Aboba köyündeki (şimdiki Pliska șehri) kalıntıları IX. yüzyılın ilk yarısıyla özdeşleşmektedir. Esasen, yazılı kaynaklarda da belirttiği gibi Asparuh (Çar İspor) bu şehri ele geçirmiştir. 1899-1900 yıllarında gerçekleștirilen kazılar (yukarıda da belirtildiği gibi), bu șehrin Preslav'dan çok daha erken tarihte Bulgar Hanlığı'nın merkezi olduğunu göstermesine rağmen, başlangıcının VII. yüzyılın sonu ya da VIII. yüzyılın tamamına atfedilmesine dair bir veriye ulaşılamamıştır. Fakat arkeolojik araștırmalar Aboba'nın eski bir Bulgar yerleşimi olduğu üzerine hemfikirdir (Georgiev 2014, 194). 1899 Ekim ayında başlayan kazılarda ilk kliseler de dâhil olmak üzere çok sayıda mimari yapı ve arkeolojik materyal gün yüzüne çıkartılmıştır. Burada keşfedilen en önemli buluntulardan biri kapı yakınında, kuzey apsis yanında yatay yatık pozisyonda bulunan Omurtag adına yapılan kolondur. 1900 yılında Sarayeri'nde gerçekleștirilen kazılarda hem Latince, hem de Grekçe ibarelerin yer aldığı yapı ya da mermer parçaları, haç tasvirli Doğu Roma sütun başlık parçaları, mermer kolon parçaları vb. rastlanmıștır. Burada ortaya çıkartılan en önemli yapılardan biri ise çoğunluğu ahşaptan inşa edilen ve muhtemel bir yangınla yok olmuş yapıdır. Duvarın hayatta kalan izlerini ayırt etmek oldukça zor olmakla birlikte, önemli bir kısmı bulunmamaktadır; ancak ibareli mermer kolon parçalarından, haç tasvirli mermer sütun başlığı ya da ne yazdığı tam belli olmayan kitabeden bir çıkarım yapılabilmektedir (Uspenskiy 1905, 10-12). 


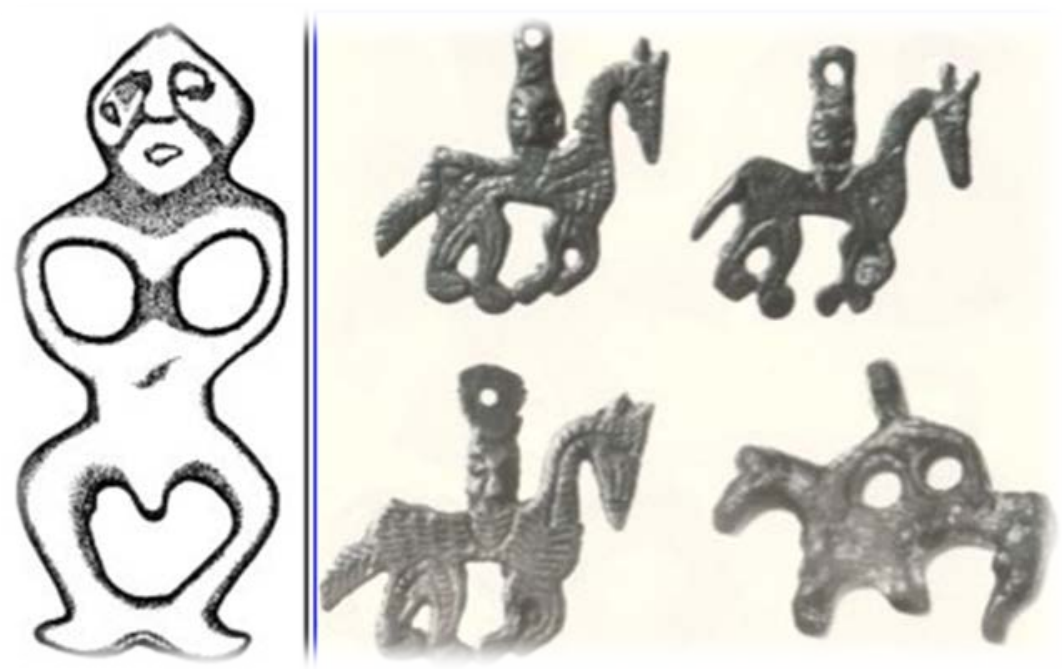

Fig. 6. VIII-IX. yüzyıla ait Bulgar buluntuları

(http://www.kroraina.com/pliska/pl_3_9.html)

Pliska üzerine yapılan tartışmalar, bu şehrin VII. yüzyılın sonundan VIII. yüzyılın son yıllarına kadar devletin merkezi olduğu yönünde ağırlık kazanmıştır. Fakat bir asırdan fazladır gerçekleştirilen arkeolojik kazılar Pliska'nın VIII. yüzyılın sonuna kadar başkent olması hakkında herhangi bir bilgi sunmamaktadır. Çok sayıda ve tartışmaya açık olmayacak tarzdaki veriler Pliska'da VIII. yüzyılın sonundan IX. yüzyılın sonuna kadar büyük yerleşim birimlerinin toplandığını ve merkez statüsünde olduğunun altını çizmektedir (Georgiev 2014, 195-196)

Tahkim edilmiş alanıyla Balkanların metropolisi şeklinde nitelenen Pliska gerçekten muntazam olmuştur. Modern keşifçiler ve ilk arkeologlar buraya, sitenin küçük bir kısmını kaplayan Türk köyünden dolayı Aboba Tahkimatı adını vermiştir. Bu Erken Orta Çağ yerleşim kompleksi, Konstantinopolis'ten üç kat büyük olmakla birlikte $21.8 \mathrm{~km}^{2}$ 'lik geniş bir alana yayılmaktadır (Fig. 2). Buna rağmen alan hakkında bilinenler oldukça azdır. Bilimsel araştırmalar uzun bir süre bu sitenin Bulgarların güç merkezi olan Pliska'ya ait olduğunu ileri sürmüştür. Fakat son dönemlerde yapılan Alman-Bulgar araştırmaları, sitenin işgali ya da gelişim aşamalarının tarihlenmesi, kökleri ile yeni ilgili farklı sonuçlara varmıştır. Sonuç olarak, AlmanBulgar ekibinin Aboba'nın 8 km batısındaki Kabiyuk tahkimatındaki benzersiz işgal yapılarını keşfinden sonra, Aboba tahkimatının tek veya gerçek "Pliska" olabileceği yönündeki geleneksel varsayım bile sorgulanmıştır. Araştırmacılara göre Pliska Ovası'nın merkezindeki arkeolojik araştırmaların yürütülmesi için iki temel metodolojik zorluk bulunmaktadır. İlki 1997'den önce Aboba-Pliska kompleksinde uygulanan arkeolojik araştırma ve analizlerin eksik oluşudur. İkinci zorluk ise Şumnu yakınlarındaki Strumba bölgesi ve Krum Han köyünün yakınlarında bulunan Omurtag sarayının sitesi gibi Kabiyuk ve Aboba tahkimatlarının muazzam alanları kaplamasıdır (Henning 2007, 212-214).

Aboba-Pliska kompleksinin diş şehrini çevreleyen genişletilmiş dikdörtgen toprak surun, 681'den sonraya tarihlendirilmesi muhtemel Pliska Ovası'ndaki konargöçer Bulgarların ilk yerleşiminden kısa bir süre sonra inşa edilen ilk yapılardan biri olduğu düşünülmektedir. $\mathrm{Bu}$ görüşe göre, kamp benzeri tahkimli bölgenin içinin batık zemin tipindeki yazlık konutlardan oluşan dağınık kırsal yerleşim kompleksleri ile kaplanmış olması muhtemeldir. Bu yerleşim alanı, taş tahkimatla çevrelenmiş saray merkezi ve aristokrat yapı komplekslerinden oluşan $D \iota s ̧$ Şehir olarak adlandırılmaktadır. Özellikle Asardere (Dış şehrin batısı) alanında yapılan arkeolojik çalışmalarda şehir yapılarına dair veriler elde edilmiştir. Yine takip eden kazı çalışmalarında Pliska'nın şehirleşme hipotezine dair unsurlar belirlenmiştir. Öyle ki bu iki yerleşim, IX. yüzyılın 
ilk yarısı ve VIII. yüzyılda veya VII. yüzyılın sonundan VIII. yüzyıla olan süreçte Aboba-Pliska kompleksinin ilk erken sosyo-ekonomik gelişme aşamasıyla birlikte düşünülmektedir. Henning'in ifadesine göre kağan ordusuna hizmet veren ve toprak surla çevrili geniş alanda yazlık konutlarda yaşayan, yönetici ikametgâhı çevresine yerleşmiş büyük bir kırsal nüfusa dikkat çekilmek istenmiştir. Özellikle Asardere yerleşimi, bazı araştırmacılar tarafından "Slav" olarak etiketlenmiş, Bulgar parti liderleri ve devleti tarafından da kabul edilen bir görüş olarak ilk Bulgar başkentinin "Slav karakter" taşıdığı iddia edilmiştir (Henning 2007, 217). Oysaki bu iddia oldukça tarafgir durmakla birlikte, siyasi amaçlar güdüldüğü şüphesi uyandırmaktadır. Bulgarlar, Tuna Havzası'na göç ederken, Hazar geleneğinin mirasçıları olarak tarım, ticaret ve zanaat alanlarında yeterli donanıma sahip olmuştur. Bu sebeple yerleşim alanını tek bir unsur ile etiketlemekten ziyade, karma bir kültür sonucunda ortaya çıktığı varsayımını yapmak daha doğru olacaktır.

Tatar arkeolog ve tarihçileri İtil-Kama şehirciliği ile Tuna Bulgarlarının şehircilik kültürünün gelişimi üzerine dikkat çekmiştir. Tuna Çukureli ve Doğu Avrupa'nın güneyi ile İtil-Kama bölgesinin birbirine olan uzaklığı düşünüldüğünde, bu bölge insanlarının ortak bir etnogeneze, kültüre yani bağlayıcı ortak bir geçmişe sahip oldukları su götürmez bir gerçektir. Bununla birlikte kazı materyalleri, İtil Bulgar şehirleriyle Tuna Bulgarlarının Tuna Havza'sında kurmuş oldukları Pliska ya da Büyük Preslav gibi şehirlerin kıyaslanmasına olanak sağlamaktadır. Bilyar ve Tuna Bulgarlarının başkenti Pliska şehrinin mimari yapılarında benzerlikler gözlemlenmektedir. Son şeklinin dikdörtgen olmasına rağmen, yapı eş merkezli olup kaleden, iç, dış şehirden oluşmaktaydı. Bu durum, yani Bilyar ve Pliska'nın benzerliği Bulgar geleneğine bağlanmaktadır. Hazar Hakanlığı'nda Bulgarlar kare formda tapınaklar inşa etmiştir. Güneşin doğduğu yöne çevrili olan bu tapınakların doğu kısmı ritüel bir anlam taşımış, taşla döşenmiş ve ocak yer almıştır. Bu tarz tapınaklara Pliska'da da rastlanmaktadır (Halikov 1976; Nadırova 2010, 20-22). Bahsedilen konu ile ilgili olarak Ögel, Bogdan Filov'un Bulgar mimarisinin menşei ile ilgili düşüncelerini de aktarmıştır. Bulgar mimari tekniği, Bulgarların gelişinden evvelki Bulgaristan mimarisinden farklı olmuştur. Bulgarlar, duvarları ve kemerleri büyük kesme taşlardan inşa ederken, Doğu Roma ve Roma binalarında, tuğla ve moloz taşları kullanmıştır. Filov'a göre Sasani tarzda inşa edilen Bulgar yapıları (Pliska sarayı) arşitektonik bir esasa dayanmaktadır. Bu mimari tarz Pliska'ya ek olarak Preslav şehrinde de gözlemlenmiştir. Pişmiş kilden yapılan su boruları, Bulgar kültüründe önemli bir yere sahip olmuştur. Pliska sarayının taşları ve suyollarına ait borular üzerinde, eski Göktürk alfabesini andıran damgalar yer almıştır. (Ögel 2014, 267). Pliska ve Preslav'ın yanı sıra birçok Bulgar yerleşiminde de keşfedilen arkeolojik buluntuların üzerindeki bu runik damgalar kimi araştırmacılar tarafından eski Türk runik yazısına kimi araştırmacılar tarafından ise Hristiyanlıkla bağlantılı Grek yazısına dayandırılmaktadır (Donçeva-Petkova 2000, 178). Özellikle Pliska'da yedi köşeli rozette ve Preslav şehrinde ise kurşun bir mühürde yer alan "IYI" işaretinin, en baskın görüşe göre tengri'nin ismini ifade ettiği, Hristiyanlığın kabulünden sonra ise hükümdar sülalesini temsil ettiği düşünülmektedir (Donçeva-Petkova 2000, 180).

Pliska yerleşim kompleksinde yaşayan halk genellikle hayvancılık ya da çiftçilikle uğraşmıştır. Merkezdeki Han'ın sarayıyla birlikte göçebe, yarı-göçebe ya da en azından kırsal müstahkem kamp, ileriki gelişmelerin başlangıç noktası olacak kompleks için yeterli bir etiket sağlamıştır. Sırlı seramik kaplar üretmek için çömlek fırınları olarak yorumlanan dört kil fırın, Asardere bölgesinde keşfedilmiş ve IX. yüzyılın sonu ila X. yüzyılda Pliska'nın sonraki sosyoekonomik gelişme aşamasıyla ilgili olmuştur (Henning 2007, 217). Yine yukarıdaki keşiflere ek olarak Pliska şehrinde günlük hayata dair çok önemli arkeolojik materyaller de gün yüzüne çıkartılmıştır. Bunlar arasında kap kacaklar (Şehirdeki kap kacaklar toprak (Fig. 5), mermer, cam ve metal malzemelerden üretilmiştir), ev ve tarım araç gereçleri, hayvan kemikleri ya da bitki kalıntıları yer almaktadır. Buluntular genellikle saray ve tahkimat yerleşimlerinde bulun- 
muştur. Tüm bunlar Pliska sakinlerinin tarım, hayvancılık, avcılık ya da farklı türdeki zanaat kollarıyla (çömlekçilik, metalürji (Fig. 6) uğraş verdiğini göstermektedir (Şkorpil 1905, 301). $\mathrm{Bu}$ durum kent ekonomisinin diğer unsurlarının ve son derece uzmanlaşmış zanaat işçiliğinin varlı̆̆ını da göstermektedir. Alandaki kulübelerin yığıntıları, Hristiyan klise komplekslerinin inşasından önce, büyük ihtimalle VIII-IX. yüzyıllara yani Hristiyanlığın kabulünden önceki dönemine tarihlenmektedir (Henning 2007, 217)

Tuna Bulgarlarının ilk başkenti olan Pliska yukarıda da geçtiği gibi, Avrupa Hunları, Hazar Hakanlığı ya da İtil Bulgarlarına (Bilyar) ait olan şehirlerde de gözlemlenen "daire şeklinde" bir forma sahip olmuştur. Bu form aslında bahsi geçmeyen diğer konargöçer şehir oluşumlarında da görülmüştür. Şehir merkezinde ahşap surlarla çevrili yönetici ikametgâhı bulunmuş; istihkâm dışında ise kalabalık olmayan banliyö nüfusu ikame etmiştir (Huzin 2006, 165).

Eski bir Türk köyü olan ve toprak tahkimatın güney kısmında bulunan Aboba köyü tarihi izler açısından oldukça önemlidir. Aboba köyünü de içine alan sur, ilk devlet merkezinin etrafını sarmıştır. Duvarın batı tarafının uzunluğu $788 \mathrm{~m}$ iken, kuzey ve güney tarafındaki duvarlar birbirine eşit; duvarların genişliği ise $2.6 \mathrm{~m}$ civarında olmuştur. Yönetici ikametgâhlarının etrafını çeviren bu surun her köşesinde silindir şeklinde birer kule inşa edilmiştir (Ögel 2014, 275). Tüm duvar hattında derin hendekler uzanmış ve kuzey tarafı bugüne dek korunabilmiştir. Tahkimatın iç kısmında büyük yerleşimin veya şehir kalıntılarına dair arkeolojik veriler (kiremit, mermer parçaları) bulunmaktadır. Hendek ve duvarlarla çevrili tüm alanın merkezi, yamuk şeklinde olan ayrı bir tahkimattır. Bu tahkimatın duvarları kesik taştan inşa edilmiştir (Uspenskiy 1905, 4). 23,3 km²' lik ve toprak istihkâmlarla çevrili Pliska'nın ortasında muhteşem bir kale $\left(0,5 \mathrm{~km}^{2}\right)$ harabesi bulunmaktadır. Bahsi geçen surun köşelerinde silindir şeklinde kuleler, yanlarında da köşeli kuleler yer alırken, kapılarında ise yine benzer formlarda kuleler yer almaktadır. Kalenin ortasındaki harabe halinde bulunan taş yapılar, 48,5×27 m ebadında bir saraya ait olmakla birlikte, bu yapı resmikabullere tahsis edilmiş $32 \mathrm{~m}$ uzunluğunda, $23 \mathrm{~m}$ genişliğinde bir salonu ve $28 \times 38 \mathrm{~m}$ ebadında bir dini mabedi (Bulgar inancına ait) barındırmaktadır. $\mathrm{Bu}$ mabet daha sonra saray klisesi haline çevrilmiştir. Bahsi geçen resmi yapıların biraz ötesinde ise $128 \times 84 \mathrm{~m}$ ebadında duvarla çevrilmiş yap1 sistemi gelmektedir. Doğu kısmında daha sağlam ve renkli taşlardan yapılan hanın odaları, batı kısmında da nispeten daha zayıf ve içeriden mermer kaplamalı olarak yapılan ve sütunlarla süslenen, han ailesinin ve çocuklarının ikametgâhı bulunmaktadır. Bunların yanı başında mutfaklar ve diğer küçük odalardan müteşekkil ilave yapılar yer almaktadır. Han'ın ikametgâhı tamamıyla dış âlemden tecrit edilmiş bir durumdadır. Attila'nın sarayı gibi yüksek bir duvarla kuşatılmıştır (Feher 1984, 72).

Asparuh tarafindan kurulan Pliska şehri, esasen Omurtag döneminde şekillenmiştir. Omurtag Han (814-831) öncesinde Doğu Roma ile girişilen askeri mücadeleler bu şehri oldukça yıpratmıştır. Örneğin tahta geçen Nikephoros (802-813) seleflerinin Bulgarlara karşı almış oldukları yenilgilerin intikamını almak için bir takım askeri seferlere girişmiş; Serdica'yı (Sofya) kuşattıktan sonra, 811 yılında büyük bir ordu toplayarak Bulgar merkezine doğru ilerlemiştir. Bu ilerleyiş karşısında, Krum Han Doğu Roma ordusunun büyüklüğünü ve donanımı göz önüne alarak meydan savaşı yapmaktan çekinerek geri çekilmiştir. Savaşmadan başkent Pliska'ya ulaşan imparator, her şeyi yağmalattığı gibi Bulgar hazinesine de el koymuştur. Kısa bir süre sonra Bulgarlar bu yenilginin intikamını fazlasıyla almış olsa da (Nikephoros öldürülmüştür) Pliska şehri harap olmuştur (Karatay 2018a, 154-155).

Pliska tahkimatlarının işlevselliğine dair fikirler arkeolojik araştırmalar neticesinde çeşitlenmektedir. Gerçekleştirilen kazı çalışmalarına göre, 895'te Macarların (Magyar) ilk beklenmedik ve ani saldırıları, iç şehrin taş surları tarafından korunan Pliska'nın sadece saraya sahip olduğunu, dış toprak surun daha sonradan inşa edildiği sonucunu ortaya çıkarmıştır. Pliska'nın Macar saldırılarına direnen kalelerinden söz edilmediği için, Pliska'nın yağmalanışı çıkarımında 
bulunulamaz. Ülkenin her yerine inşa edilmiş olan pek çok benzeri gibi, Pliska'nın büyük dikdörtgen biçimli toprak suru da gelecek Macar istilasına karşı daha iyi korumayı sağlamıştır. Bunlar, sadece çalkantılı durumlarda koruma görevi üstlenmemiş aynı zamanda özellikle Simon hükümdarlığında (893-927) yani X. yüzyılda Bulgarların “Altın Çağı”nı da güvenceye almıştır (Bu çalışmada Asparuh'un yönetim merkezi (VII. yüzy1l), Krum Han'ın avulu gibi unsurların da yer aldığı görseller bulunmaktadır. Henning 2012, 1-2).

Yukarıda bahsi geçen birçok yapının banisi Omurtag Han olmuştur. Omurtag zamanında taş saray ve çevresindeki duvarlar inşa edilmiş; fakat toprak duvar ve hendeklerle tahkim edilmiş, Bulgar kamp1 ya da köyü VIII. yüzyılda burada var olmuştur (Uspenskiy 1905, 15). 1981 yılında R. Raşeyev tarafından büyük bir pagan tapınağının önünde yerleşmiş yarı kazılı bir yurt keşfedilmiştir. Detaylarına inildiğinde ise bu yapı bir konuttan çok bir anıta benzemekte ve büyük olasılıkla da 814 yılında Pliska'da ölen Krum Han'ın anıt kompleksinin bir parçasını oluşturmaktadır (Georgiyev 2014, 203). Yukarıda da bahsi geçen ve doğu menşeli mimari teknikle Omurtag Han tarafından Pliska'da inşa edilmiş olan sarayın büyüklüğü $52 \times 26 \mathrm{~m}$ olmakla birlikte, dış duvarların kalınlığı $2.5 \mathrm{~m}$ ve iç duvarlarınki ise $1.5 \mathrm{~m}$ kadardır. Ortaya çıkan kalıntılardan koridor ve mihrap kısmının doğu ve batı duvarlarında beşer menfez, salonların ise kubbelerle kaplanmış olması muhtemel gözükmektedir. Surun, kuzey tarafına bitiş olarak inşa edilen büyük saray, başlıca iki salondan oluşmuştur. Bununla birlikte araştırmalarda saray içerisinde mutfak ve harem bölümlerine dair veriler de ortaya çıkmıştır (Ögel 2014, 278).

\section{Preslav}

Tahta geçtikten sonra Konstantinopolis kuşatmasından vazgeçip, Doğu Roma ile 30 yıllık bir anlaşma imzalayan Omurtag Han (814-831) yıkılan Pliska'yı onarmış; aynı zamanda yeni başkent olacak olan Preslav şehrinin temellerini atmıştır (Karatay 2018b, 159). Fakat Preslav'ın başkent olması Omurtag Han'ın haleflerinden Simon (893-927) zamanında gerçekleşmiştir. Preslav'ın varlığı hakkında ilk bilgiyi veren kaynaklardan biri Omurtag'ın Çatalar Yazıtı'dır. Bu yazıtta Tanrı tarafından tahta çıkartılmış olan Omurtag Han'ın Pliska'da ikamet ettiğinden, Tisa istihkâmlarını ve Tisa üzerinde bir köprü yaptırdığından bahsedilmektedir. Ama bu yazıtta esas önemli olan inşa ettirmiş olduğu kalenin içine dört sütun ve sütunların arasına iki aslan koydurmasından bahsedilmiş olmasıdır. Gerçekten yazıtta bahsedilen sütunlu ve giriş avlusunun aslanlarla süslendiği saray kalıntılarına Preslav kazılarında rastlanılmıştır (Ögel 2014, 281).

V. Antonova ve S. Dremsizova 822 yılına ait sütun başlığında bahsedilen Omurtag'ın sarayını keşfettiklerini belirtmiştir. Bu bilim insanları, bina ve tahkimat kompleksinin, sütunun bulunma yerine yakın (Çatalar) bir konuma getirilmesini ve bir sürü başarılı kazı çalışmasının gerçekleşmesini başarmıştır. Sonuçta antik veya eski bir Doğu Roma yerleşimi olarak, önceden sınıflandırılmış büyük bir dikdörtgen sur tahkimatının daha sonra yeniden inşa edildiği ve sonradan önemli bir Erken Orta Çağ müstahkem idare merkezi olduğu ortaya çıkmıştır. Bu babda Çatalar tahkimatının tüm iç saray alanının ortaya çıkartılmasından sonra şüphe edilecek bir durum kalmayarak, Omurtag'ın avulu bulunmuştur (Henning \& Balabanov vd. 2007, 437). Omurtag Han, 821-822 yıllarında bu civarda bir kale inşa ettirmiş ve bunun dış surlarını da taştan ördürmüştür. İç kale 1,4 kilometrekare olup büyük dört köşe taşlardan yapılmıştır. Kalede bulunan harabeler hakkında ise kesin bir fikre ise sahip olunamamaktadır (Feher 1984, 73).

Preslav'ın Pliska'nın yerini alması idari ve sosyal sorunlar çerçevesinde gerçekleşmiştir. Öyle ki Hristiyanlığı kabul eden Boris, Bulgar tarihini değiştirecek önemli bir adım atmıştır (864). Boris, Hristiyanlığ kabul ettikten sonra Bulgar topraklarını bu yeni seçiminde yönlendirmiştir. Bununla birlikte uzak ve yakın mesafedeki devletlerle bağını güçlendirmek için elinden geleni yapmıştır. Bulgar topraklarında merkezi değişim, onun 889 yılında manastıra çekilip tahtı oğlu Vladimir'e bırakmasıyla bağlantılıdır. Hristiyanlık yerine eski dinlerini yaşatmadan yana olan Vladimir, bazı soylu aileleri de yanına alarak ülkede uzun süren dini ve 
etnik çatışmalara sebebiyet vermiştir. Bu yeni dine geçiş ise halk tabanında hiç de olumlu karşılanmamış; veliaht Vladimir'in de başını çektiği bir kısım halk eski inançlarını sürdürmeye devam etmiştir. Din bazlı ortaya çıkan kaos, kanlı müdahalelere sahne olmuştur. Bu sebeple babasının müdahalesi ile taht hâkimiyeti Vladimir'den alınıp üçüncü oğul Simon'a devredilmiştir (Jireçek 1978, 175-178). Bununla birlikte eski usullerden kopulduğunun açıkça görülmesi için devletin merkezi Pliska'dan taşınmıştır. Yeni başkent ise meclisin toplandığı (Tisa Nehri'nin kıyısında yer alan eski bir Bulgar kalesi-Veliki Preslav "Türkçe Eski İstanbul” yer olarak ilan edilmiştir (Jireçek 1978, 185). Bu hususta Boris'in çabaları ve oğlunun fedakârlığı boşuna olmamıştır. Boris'in aksine oğlu Vladimir, Bulgar topraklarında Hristiyanlığın kökünü kazımak için elinden geleni yaparken, onun sonrasında iktidara gelen Simon, otuz dört y1l hüküm sürerek (893’ten $927^{\prime}$ e), kolaylıkla selefinin bıraktığı etkiyi yok etmeyi başarmıştır. Hükmettiği süre boyunca gücünü kullanarak hem devleti, hem de kültürü genişleterek büyütmüştür. Simon'un çabaları neticesinde Veliki Preslav'ın takviye edilmiş küçük yerleşimi, daha da gelişerek bir başkente dönüşmüştür (Stancheva 1993, 5-6).

Simon hükümdarlığında gelişen Veliki Preslav'da artık Çar/Veliki unvanın kullanılmasına karar verilmiştir. Pliska'da ise yaşam diğer Bulgar şehirlerinde olduğu gibi günlük seyrini takip etmiştir. Fakat Pliska ebedi olarak, Bulgar devletinin kurucu isimleriyle bağlantılı olarak kalmıştır. Devlet tam olarak Pliska'da kurulmuş ve sonraki dönemlerde kurucu Asparuh'un izlerini taşımıştır. Krum Han zamanında da başkentlik yapmış olan Pliska, özellikle Omurtag Han'ın ve onun barışçıl hâkimiyetini simgeleyen yazıt ve sütunlarla kaplıdır. Son olarak Pliska, Boris'in Hristiyanlığı kabulünden sonra ülke boyunca resmi din olan Hristiyanlığın kabul edilmesinde belirleyici bir adım üstlenmiştir. Oysaki her Bulgar tarafından kutsal değer olarak bilinen eski başkent Pliska, kağanlar ve eski Proto-Bulgar geleneklerini izleyen devlet için tasarlanmıştı. Bir orduyu barındırabilen geniş $d \iota$ ş şehir, hendek ve surlara çevirili olan bina ve imalathanelerle birlikte bir askeri kamp yerini anımsatmıştır. Kağan'ın saray ve çevresiyle birlikte iç kale duvarı, başka bir kaleyle korunmuştur. Ne yazık ki Pliska'da Bulgarların ata dinlerine ait tapınaklar kiliselerle yer değiştirmiş, iç kale yakınına manastır ve bazilika inşa edilmiştir; Hristiyanlık öncesini hatırlatan her şey yok olmuştur. Pliska'da din uğruna çokça kan dökülmüş, bu durum şehrin Hristiyan Bulgarlarının başkenti olmasını zorlaştırmıştır (Stancheva 1993, 9-10).

Preslav'ın Tuna Bulgarlarına başkent olmadan önceki ya da başkent olma durumu hakkında kaynaklar çok az bilgi vermektedir. Bu kaynaklardan biri Honiates'in eseridir. XII. yüzyıl, Hellen asıllı Doğu Romalı bir tarihçi ve diplomat olan Nikitas Honiatis, Asen ve Peter kardeşlerin başlattığı kurtuluş hareketiyle (Doğu Roma'ya karşı XII. yüzyılda gerçekleşen isyan), Peter'in Çar olarak ilanında sonra, Bulgar ordusunun Preslav'a yöneldiğini belirtmiş ve Preslav'ın ise Haimos'la (Antikçağda Balkan dağlarına verilen isim) çevrili, pişmiş tuğladan yapılmış çok eski bir şehir olduğunu belirtmiştir. Honiates bahsedilen olayların çağdaşı olduğu gibi, imparator II. İsakios Angelos'un Bulgarlara karşı gerçekleştirdiği seferde yer almış; şahsi kâtip olarak Bulgarlar ve ülkeleri hakkında da bilgi sahibi olmuştur. Honiatis anlatımlarında bu şehrin büyüklüğüne ve sağlam tahkimatına dikkat çekmiştir. Aynı zamanda Preslav'ın eskiliği üzerinde durmuştur. Preslav şehri hakkında yine Doğu Roma kaynaklarında, bu şehrin Pliska, Drastar/Drustar (Silistre), Konstantsia (bugünkü Köstence) ile Büyük Konstantinos tarafindan (305-336) inşa edildiğinden bahsedilmektedir. Daha sonradan Anna Komnena, İst'r/İstar'da bulunan ünlü şehrin Bulgar-Prislav ismini almadan önce, Hellence megapolis anlamina gelen Büyük Şehri ifade ettiğini vurgulamıştır. Şehir bu suretle Megali Prislava olarak adlandırılmaya başlanmıştır. Geleneksel Bulgar literatüründe bu, Veliki Preslav olarak düşünülür ve sıfatın iki anlamı bulunmaktadır. Bulgar kroniklerinde de büyük bir şehir olarak geçer ve Hellen yazarların ifade ettiği gibi büyük anlamındadır. Büyük şehir olarak kullanımı ya da yansıması kendi çağdaşları tarafından Konstantinopolis göz önüne alınarak gerçekleşmiştir. Yeni Roma olarak sayılan ve Büyük Roma ile karşılaştırılan Preslav'ın büyük olarak adlandırılması, Çar I. Simon 
(893-927) ve I. Peter (927-969) ile ilgili görünmektedir ki, bu iddia da haklılık payı vardır (Georgiyev 2013, 14- 15).

Simon, Bulgarların Tsarigrad dedikleri Konstantinopolis’te yaşamış ve eğitim görmüştür. Burada gördüğü eğitim sırasında, Konstantinopolis’i kuran Büyük Konstantinos’tan çok etkilenmiş olacak ki, tahtın başına geçtikten sonra, hem Bulgarlara yakışacak hem de yabancıları etkileyecek bir başkent kurmayı tasarlamıştır. Bu hususta gerçekten de başarılı olmuştur (Stancheva 1993, 12). Dönemin önemli bilginlerinden John the Exarch'ın Preslav'1 tasvir edişini Stancheva şu şekilde aktarmıştır:

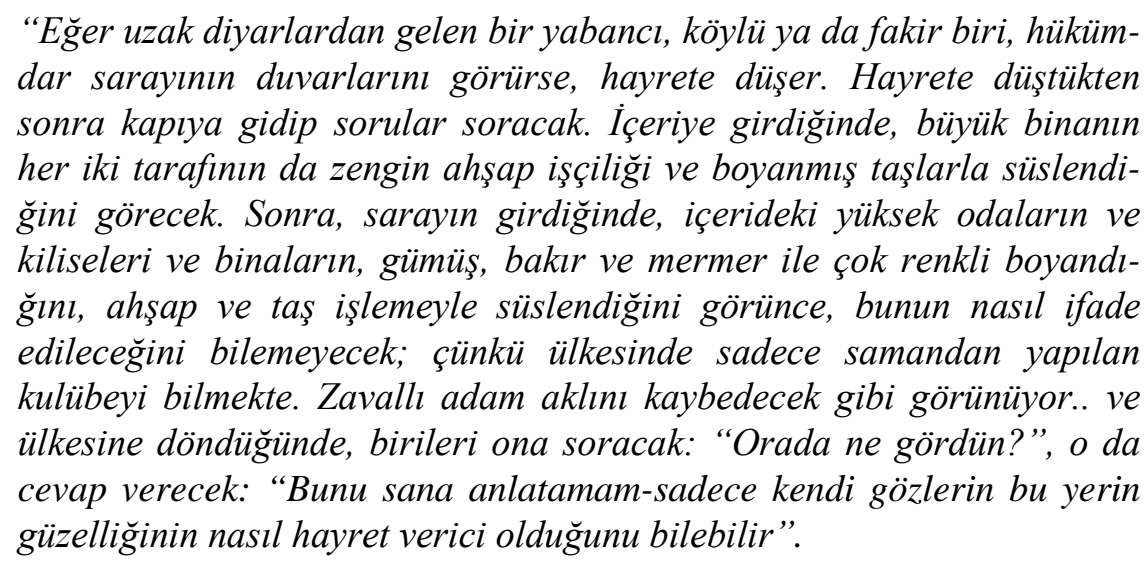

Bu bilgiler kısa olsa da Simon, tarafindan kurulan ikinci Bulgar başkentinin ne kadar zengin ve ilgi çekici olduğunu anlamaya yetmektedir (1993, 12-14).

Preslav'ın konumu ise uzun süren tartışmaları beraberinde getirmiştir. X. yüzyılın Bulgar başkentinin müstahkem toprakları çevresinde bulunan arkeolojik kalıntılar, XI-XIII. yüzyıldaki hayali görüntülerin tarihsel bir gerçeği yansıttığını varsaymak için bazı gerekçeler sunmuştur. $\mathrm{Bu}$ alan Tisa Nehri vadisinin önemli kısımlarını içermektedir. Bu durum şehrin sınırlarını Konstantinapolis'i bile aşan bir Megapolis gibi hiperbolize etmeye hizmet etmiştir. Bu sebeple Eski İstanbul (Stambul) (Bugünkü Veliki Preslav) olarak adlandırılmıştır. P. Bogdan bu düşünceye göre, şehri Şümen'den 5 mil uzakta (aslına yaklaşık 7,5 km uzaklıkta, fakat Krum Han kırsalında Omurtag avlusuna) yerleştirmektedir. P. Jorjic ise bunu Prislova-terra olarak tercih etmiştir. Genellikle kaynaklar ya da araştırmalar eski Bulgar başkentinin kalıntıları olarak Tisa Nehri vadisinde Çar Simon ve Boris Mihail zamanından kalma kilise yapılarını işaret etse de, bu durum içerisinde bulanıklar ve eksikler barındırmaktadır. Yukarıda bahsi geçen Nikitias Honiates'in tarihinde Megalipolis Preslav'ın genişletilmiş tasviri, ilk olarak Omurtag avulundaki yapı ve kaledeki tuğla duvar göz önüne alınarak pişmiş tuğladan ibaret şehir olarak yazılmasına neden olmuştur (Georgiyev 2013, 26- 27).

XVII. yüzyılda Roma eğitim görmüş olan P. Bogdan Bakshev Preslav'la ilgili şu açıklamalarda bulunmuştur:
"Burası günümüzde kalıntıları olan, zamanında ise beyaz kesme taşlarla inşa edilmiş eski söylemiyle Eski Starigrad (Old Constantinople) Türkçe'de "Eski İstanbul", olan büyük bir şehirdir. Prislavan ismi (Slav dilinde) muhteşem şehir demektir. Bu günlerde Türkler (Osmanl), yeni evlerini inşa etmek için kesme yapı taşları alarak tahrip etmektedir. Şimdilerde burası köy yakınlarında. Burada birçok yerde taş üzerinde Slavca yazllmış ifadeleri görebilirsiniz, fakat çoğu tahrip edildiğinden dolayı bunlardan bir anlam çıkaramazsınız” (Stancheva 1993, 14).

Preslav'da en büyük yapı olan bazilika 923-925 yılına tarihlenebilir; Simon o dönemde yeni 
Preslav'ın var olmasına rağmen, eski başkentin yapımıyla da ilgilenmiştir. Çünkü araştırmalara göre Simon'un çocuklarına yeni bir başkent inşasını atfetmek için hiçbir neden bulunmamaktadır. Bu sebeple hem eski kentin, hem de yeni Preslav'ın eşzamanlı varlığına Bulgarların Hristiyanlığı kabulünden sonrasında da rastlanabilmektedir. X. yüzyıla ait para buluntuları ve bazı kitabeler, eski Bulgar başkentinin yıkılmadığına ve Simon zamanında terk edilmediğine bir kanıt teşkil eder. Hatta X. yüzyılda Svyatoslav'ın seferine kadar eski başkent bu özelliğini korumaya devam etmiş olabilir (Uspenskiy 1905, 15).

Arkeolojik kazılarda mermer dekorasyonun kullanıldığ 1 Veliki Preslav'da her ana binanın yanında ocak-çukurlar keşfedilmiştir. Türk-Bulgar egemenliğindeki binaların yapımı için kullanılan yapı malzemeleri ve duvarların sıvası için en iyi kireç taşından mermer üretilmiştir. Preslav'da görülen beyaz kesme kireç taşları, eritilmiştir. Kireçtaşı, süslemelerle birlikte iç içe geçmiş yapraklı bezemelerde, özel oluk ve zemin döşemesinde, sırlı ve boyalı kil karolarda kullanılmıştır. Arkeolojik keşifler, ocak-çukurlarda parçalanan ve bozulan heykellerin, mimari süslemelerin güzelliği hakkında fikir vermektedir. (Stancheva 1993, 16). Veliki Preslav, Çar Simon'nun 927'de ölümünden sonra Çar Peter zamanında da başkent olmaya devam etmiştir. Bu dönemde Kievli Ruslar ve Doğu Roma ile çatışmalar baş göstermiş, Veliki Preslav'a iki Rus saldırısı gerçekleşmiştir. Rusların, Preslav'ı kuşatması Rus vakayinamelerinde şu şekilde yer etmiştir: "Svyatoslav Tuna'ya Bulgarların üzerine gitti. Her iki taraf karşılaşarak savaştılar. Svyatoslav, Bulgarlart yendi ve onların Tuna boyundaki 80 şehrini aldl. Preslav'da knezlik yaparak Greklerden de vergi aldı (967)" (Polnoe sobranie Russkih’ letopisey 1846, 27; Yücel 2007, 489). İkinci saldırıda Preslav şehri kuşatılmış, fakat Doğu Roma-Rus ilişkileri bu durumun devamlılığını engellemiştir. Fakat Preslav 972'de Doğu Roma ellerine düşmüştür. Doğu Roma, başkent alevler içindeyken bu durumu kutlamıştır. Bulgar topraklarını fetheden İmparator I. Ioannis Tzimiskes, kale duvarlarının tamiri için emir vermiş ve şehrin Ioannopolis (John'un şehri) olarak adlandırılmasını ilan etmiştir. Stancheva'ya göre bu şehre imparatorun kendi kişisel ismini vermesi ne kurucu Simon ne de varisinin kendilerine izin vermediği bir küstahlık olmuştur. Yine Ioannis bu yolla ismini devam ettirmek istemiştir. Fakat bu arzusu devam etmemiş, Ioannopolis ismi oğlu zamanında unutulmuştur. Doğu Roma kaynakları, imparatorun ülkesine dönerken Bulgar hazinelerini de götürdüğ̈̈nü yazmıştır. Bunlar arasında kraliyet taçlarının ve Bulgar hükümdarların kraliyet gücünün diğer sembolleri yer almaktadır (1993, 16).

Tuna Bulgarlarının tahkimat duvarları oldukça ilginçtir. Tuna Bulgarlarını, Tuna Çukureli'nin kuzey ve kuzeydoğusunda, 130 km’lik yı̆̆ma duvar korumuştur. Bu Bulgar Hanlığı'nın hem kuzey sınırı hem de Tuna'nın 40 km kuzeyindeki sulak bölge ve step arasında doğal-coğrafi sınır olmuştur (Nadırova 2010, 23). Preslav bölgesindeki bu surlar 1897 yılında ilk kez Zlatarski tarafından keşfedilmiştir. Preslav surlarının, yapı tekniği Pliska surlarına oldukça benzemekle birlikte, birçoğunun 821-822 yıllarında Omurtag Han tarafından yaptırılmış olmaları muhtemeldir (Ögel 2014, 276). Beyaz taş ve tuğladan gerçekleşen inşa tekniği, Sasani etkisi altında olan Tuna Bulgarlarında da oldukça popüler olmuştur (Nadırova 2010, 26). Fakat G. Feher'e göre Pliska ve Preslav gibi şehirlerde bulunan surlar ve kargir saraylar plan ve malzeme bakımından, çağdaş Doğu Roma tekniğinden oldukça farklıdır (1984, 71). Onun fikrine göre Tuna Bulgar tabyalarının menşei Çin'dir. Çin'de de müstahkem mevkilerin duvarları çamurdan yapılır, çamurun içine çakıl taşları, kamış parçaları ve dal demetleri konularak, dayanıklılık sağlanırdı (Ögel 2014, 261). Preslav tahkimat duvarlarının varlığı, görgü tanıklarının kayıtlarına göre XVIII. yüzyıla kadar sürmüş, bu tarihten itibaren ise eski tahkimatlara ait yapı malzemelerinin yeni oluşumlar için tahribata uğramaya başladığı anlaşılıışır (Georgiyev 2013, 15).

Gerek tahkimat yapılarının varlığı gerek ise tabyaların devasa uzunluğu Tuna Bulgarlarının 
güvenliğe ve askeri yapılara verdiği önemi gözler önüne sermektedir. Bu durum çok tabi olarak Tuna Bulgar yerleşimlerine de yansımıştır. Preslav da dâhil olmak üzere diğer Bulgar yerleşimlerinde gerçekleştirilen kazılarda askeri temalı kalıntılar ortaya çıkartılmıştır. Örneğin Preslav'da 1945 yılında keşfedilen askeri teçhizat temalı bir Bulgar kitabesi (IX. yüzyı1), Hellen alfabesiyle yazılmış olmasına rağmen içerisinde hiçbir şekilde Hellence kelime içermeyip, Proto-Bulgar diliyle kaleme alınmıştır. Bu kitabenin en önemli özelliği Tuna Bulgar dilinin Çuvaşça, Tatarca vb. gibi Türk dilleriyle olan akrabalığını ortaya koymasıdır (Venedikoff 1947, 540-556). Konumuz açısından ise dikkat çeken yönü Preslav şehrinin Hristiyanlık kabulü öncesinde de (çoğunlukla Omurtag Han dönemi) bir Bulgar merkezi olmuş olmasıdır.

IX. yüzyılın sonuna doğru Bulgar topraklarında feodal toplumda görülen temel sınıflar gözlemlenmeye başlamıştır: feodaller ve toprağa bağlı köylüler. Bununla birlikte feodal şehirlerin oluşumu da ivme kazanmıştır. Örneğin Pliska ve ikinci Bulgar başkenti olan Preslav bunlardan bazılarıdır (Simakova 2007, 2). Preslav şehrinde zanaat ve tarım oldukça aktif faaliyet gösteren başlıca iş kollarından olmuştur. Örneğin Bulgar çanak-çömlekçiliğine ait buluntular, bu eserlerin tekniğinin Doğu Roma ve İslam seramiğinden daha yüksek bir kaliteye sahip olduğunu göstermektedir. Eserlerin kimyasal analizleri, kil toprağın Preslav'a ait olduğunu göstermektedir. Bu çiniler, doğu sanatına has bir şekilde duvarları kaplamak için de kullanılmıştır (Ögel 2014, 283). Preslav'da bulunan zanaat ürünlerinin birçoğu XI. yüzyıla tarihlenmektedir. Bulgar üretim komplekslerine, Preslav'da bulunan Novosel ve Zlatar köylerinde yoğun olarak rastlanmaktadır. Bu komplekslerden her biri 3-5 farklı atölyeden oluşmaktadır. Çalışma alanları birbirine yakın yerleştirilmiştir. Keşfedilen buluntular arasında ise kemer uçları, küpeler, yüzükler, tokalar, madalyonlar vb. yer almaktadır (Donçeva 2017, 194-196). Yine 1949'da iç kalenin güney kapısının çevresinde yer alan buluntuların arasında altın kaplama (Stancheva 1993, 17) bir materyale rastlanılmıştır. Bu 336 gr. ağırlığında olup altından (22 karat) imal edilmiştir. Üzerine hac işlemeli bu tabak, kiliselerde yaygın olarak kullanılan sözlerle süslenmiştir. Büyük ihtimalle Konstantinopolisli zanaatkârlar tarafından imal edilen bu tabak, Veliki Preslav'a hediye olarak gelmiş; sonrasında ise çalınmıştır (1993, 17-18).

Tarımın Bulgar toplumunda ne denli önemli olduğu özellikle arkeolojik araştırmalar neticesinde ortaya çıkmıştır. Fakat N. Hrissimov bu hususta farklı ve güzel bir değerlendirme yapmıştır. Orta Çağ Bulgarlarının yeme alışkanlıkları üzerinde duran Hrissimov, VII-XI. yüzyıllarda Bulgar topraklarında ne tüketildiğini anlamak için iki ana bileşene dikkat çekmiştir: Slav ve Bulgar beslenme alışkanlıkları. Slavlar, İtalyan darısı ve yaygın olarak darı, depolanan her türlü hayvan ve ürün bolluğuna sahip olmuş; bu sebeple bitkisel ve hayvansal unsurları birleştiren çok çeşitli bir yeme alışkanlığına sahip olmuştur. Bulgarların ise diğer göçebe toplumlarda olduğu gibi gıda tüketimlerini daha çok et ve süt ürünleri oluşturmuştur. Tuna Bulgarlarının yeme alışkanlığı ya da gıda tüketimi ile ilgili verilerin ortaya çıkması tamamen bölgede gerçekleştirilen arkeolojik ve arkeobotanik çalışmalar sayesinde gerçekleşmiştir. Bunlar neticesinde Tuna Bulgarları, bölgeye yerleştikten sonra çavdar, darı, arpa, karabuğday, 1sırgan, mantar, armut, kiraz kavun, karpuz vb. mahsulleri tüketmiştir (2017, 1-65).(Fakat bu ürünlerin her yerde aynı oranda tüketildiği manasına gelmemektedir; sadece arkeobotanik verilerle desteklenen yazılı kaynaklar böyle bir tablo sunmaktadır.) Hrissimov, Bulgar devletinde uygulanan ve ilk Doğu Roma yasalarından biri olan Çiftçi Yasalarında mahsullerin farklı türlerine atıfta bulunma sıklığına dayanarak, Hristiyanlaşmayı takip eden dönemde Bulgar çiftçisinin temel odağının tahıl bitkileri ve üzüm bağı tarlaları olduğu fikrini savunmaktadır. Hasattan sonra tahıllardan elde edilen mahsuller, harman tahtaları ile ögütülmüş ve evin tabanına oyulmuş çukurlarda ya da çömlek kaplarda saklanmıştır (2017, 66-69). Benzer olarak çukur formundaki bu depolara İtil Bulgarlarında da rastlanılmaktadır. Hemen hemen her evde tahılları saklamak için çukur ya da ambarlar bulunmuştur (Smirnov 1951, 237-241). Çanak-çömlek buluntuları, saray, aristokrat evlerinde ya da manastır komplekslerinde tipik olarak tahıl depolandığını göstermiştir. 
Bulgaristan'da VII-X. yüzyılda insanlar, tahıl rezervlerini evde veya dışarıda bahsi geçen özel çukurlarda depolamıştır. Bu çukurlara ek olarak, yerleşim yerlerinde tahılların depolanabileceği ambar olarak kullanılan yapılar da bulunmaktadır. Orta Çağ'da Bulgarların temel bir gıda maddesi olarak tahılların öğütülmesinin yaygın olarak kullanımının, Tuna Bulgar Devleti’nin yerleşimlerinde değirmen taşlarının varlığıyla altı çizilmektedir. Örneğin Pliska'da bu tarz değirmen taşlara ve öğütülmüş tahıllara rastlanılmaktadır (Hrissimov 2017, 66-69).

Hem Preslav hem de Pliska şehirleri ticaret, zanaat ve tarım potansiyeli yüksek olan sahaları teşkil etmiştir. Şehirleşmenin hız kazanması ise bu iş kollarının gelişmesi ile doğru orantılı olmuştur. Üretimin iç piyasaya yönelik faaliyeti, zamanla standartlaşmayı ve dışa satımı da beraberinde getirmiştir. Yukarıda bahsi geçen ürün depolama alanları, üretimin arttığını ve şehirleşme adına adımlar atıldığının bir göstergesidir. Öyle ki şehir nitelikli yapıların oluşumuna ev sahipliği yapmış olan her Orta Çağ yerleşiminde olduğu gibi köylerde üretilen tarım ve zanaat ürünleri, büyük ölçekli yerleşimlere aktarılarak hem ticari hem de merkezi gelişim yaşanmıştır. Refahın artması beraberinde korunaklı yapıların ve yolların oluşumuna yani bir şehrin olmazsa olmaz unsurlarına zemin hazırlamıştır.

\section{Sonuç}

Bugün Tuna Bulgar şehirleri hakkında bilgi sahibi olmak istediğimiz de başvuracağımız ilk adres arkeolojik çalışmalardır. Yazılı kaynaklarla karşılaştırılmalı değerlendirmeye tabi tutularak ele alınan arkeolojik kaynaklar bir şehrin mimari, kültürel, dini, askeri ve politik yapısını aydınlatma hususunda oldukça başarılıdır. Öyle ki Tuna Bulgarlarının ilk başkenti Pliska ve sonraki başkenti Preslav'ın canlı bir siluete kavuşması keşfedilen arkeolojik materyaller sayesindedir. Biz bu keşiflerin yazıya dökülmesi sayesinde, Tuna Bulgarlarının ilk olarak tutundukları yurdun neresi olduğu ya da inşa edilen surların işlevselliğinin ne olduğu gibi sorulara cevap bulabilmekteyiz. Bu tarz sorular çoğaltılabileceği gibi, sorulara bulanabilecek yanıtlar da bir o kadar çeşitlenebilir. Zira çalışmamızda da bahsi geçtiği gibi birçok hususta (Tuna Bulgar yurdunun sınırları, bir yerleşimin şehir sayılabilmesi için gereken hususlar vb.) araştırmacılar, arkeolojik ve özellikle de yazılı kaynakları kendi fikrine göre ele almış ve farklı pencerelerde değerlendirmiştir.

Arkeolojik çalışmalar neticesinde gün yüzüne çıkartılan Bulgar yerleşimlerinin bir şehir hüviyetinde olup olmadığı sorunsalı ise çalışmada da bahsi geçtiği gibi tam bir netlik kazanmamıştır. Bir yerleşimin şehir olarak nitelendirilebilmesi için kabul edilen kıstaslar (nüfus, korunaklı yapılar, ekonomik işlevsellik vb.) coğrafyaya ve topluma göre farklılık arz etmektedir. Özellikle coğrafyanın insan üzerinde oynadığ 1 rol ile belirginleşen kültürel değerler, yerleşimlerin karakterizasyonu için oldukça önemli olmuştur. Bu sebeple yüzyıllar boyunca belirli aralıklarla doğudan batıya gerçekleştirilen göçlerde devletleşmeyi başaran Türk kavimlerinin bazıları (Hunlar, Bulgarlar, Hazarlar vb.) yerleştikleri coğrafyaya ve iklime göre Türk yerleşim standartlarında da değişime gitmiştir. Değişimin en büyük nedeni ise göç edilen yeni topraklarda karşılaşılan otokton halkın coğrafyayla bütünleşmiş alışkanlıklarıdır. Sonrası ise devletleşmenin askeri, idari ve iktisadî yapılara duyduğu ihtiyaçla alakalı olmuştur. Bu açıdan bakıldığında Tuna Bulgar şehirleri gösterişli surlarla çevrili şehir komplekslerine sahip olmuştur. Bu kompleksler içerisinde müstahkem ikametgâhlar, dini tapınaklar, konutlar, zanaat ve ticaret yerleşimleri (sur dışında da olsa dâhil edilmelidir) yer almıştır. Kimi araştırmacılara göre tüm bu öğeler Doğu Avrupa Orta Çağ şehrinin oluşumu için yeterli kıstaslar olarak belirtilirken, kimi araştırmacılar için ise şehir oluşumu için öncelikli kıstası nüfus yoğunluğu ve bu nüfusun yaşadığı alan (sur içi-sur dışı) oluşturmuştur. Bu sebeple çalışmamız Tuna Bulgar yerleşimlerinin şehir olarak nitelendirilip nitelendirilmeyeceği üzerine yoğunlaşmamıştır. Fakat bizim kanaatimize göre yukarıda sayılan kıstaslar Orta Çağ'da Doğu Avrupa Türk şehirciliği için yeterli görülmekte ve bir yerleşimi şehir hüviyetine sokan unsurlar arasında sayılmaktadır. 
Arkeolojik kaynaklara istinaden yazılı kaynaklar Tuna Bulgarları hakkında çoğunlukla sessiz kalmayı tercih etmiştir. Arap kaynaklarında ne yazık ki Tuna Bulgarlarına dair pek fazla bir bilgi bulunmamaktadır. Bu kaynaklarda da Bulgarlar genellikle iç ve dış şeklinde ayrılmıştır. Örneğin X. yüzyıla ait anonim bir eser olan Hudûd el-âlem'de İç Bulgarlar ile kastedilen İtil Bulgarları olmuştur (Hudûdü'l-Âlem, 120). Mesudî, Bulgarların güçlü ve vuruşkan bir halk olduğunu belirttikten sonra Konstantinopolis halkının Bulgarlardan ancak surlar sayesinde korunduğunu, diğer halkların da onlara karşı kale ve surların olduğundan bahsetmiştir. Fakat Mesudî Bulgarlar ile bilgi aktarırken, bazı yerlerde İtil ve Tuna Bulgarlarına dair bilgileri karıştırarak okuyucuya sunmuştur (Mesudî, 74). Arap kaynaklarının aksine Doğu Roma kaynakları, Doğu Roma ile siyasi, askeri ve ticari ilişkilerde bulunan Tuna Bulgarlarının siyasi, kültürel ve askeri hayatları hakkında bilgi vermiştir (Theoph. Chronographia 498-499; Niceph. Br. Hist. 35-43). Verilen bu bilgilerde Tuna Bulgarlarının yerleşim yerlerine ya da şehirlerine ilişkin kısımlar yok denecek kadar azdır.

Doğu Avrupa'nın Orta Çağ tarihinde at koşturan birçok Türk kavmi gibi Tuna Bulgarları da Karadeniz düzlüklerinden Balkanlara derin tesirler bırakmıştır. Her şeyden önce modern dönemde konargöçer tanımının arkasına sığınılarak yapılan anti-medeni yorumlara en güzel cevabı veren Türk kavimlerinden biri Tuna Bulgarları olmuştur. Hazar gibi köklü bir mirasın temsilcileri olan Bulgarlar, Asya topraklarında edinmiş oldukları kültürel kazanımları batıya göç ettikçe zenginleştirmiş, Tuna'da inşa etmiş oldukları şehirlerde doğu ve batı sentezinin en güzel örneklerini vermişlerdir. Bununla birlikte Orta Çağ'da tıpkı akrabaları İtil Bulgarları gibi Türk tarzı şehircilik kültürünün en güzel temsilcilerinden biri olmuşlardır. Tuna Bulgarlarının Hristiyanlığ 1 kabul etmesi, yukarıda da bahsi geçtiği gibi şehircilik anlayışında bir takım farklılıklar doğmasına neden olmuştur. Ama bu farklılığın Hristiyanlığın resmi olarak kabul edilmesinden bir yüz yıl öncesinden çok da değişik olması beklenemez. Zira Tuna Bulgar topraklarında Slavların ve Slavların hamisi olan Hristiyanlığın yayılımı ilk başkent olan Pliska'nın var olmasından bu yana ivme kazanmaya devam etmiştir. Bu durum hem Doğu Roma hem de Roma'nın Bulgar topraklarına yakınlığı ile ilgilidir. Her ne kadar Bulgar toplumu kendi kültürünü yaşamaya devam etmiş olsa da, Tuna Bulgar Hanlığı'nın önemli bir kısmını oluşturan Slavların Hristiyanlığ benimsemeye başlaması ile Bulgar yerleşimlerinde Hristiyanlık unsurları artmıştır. Zira Tuna Bulgarları hanlık bünyesinde daha çok askeri anlamda, Slavlar ise kültürel anlamda ön plana çıkmıştır. Bu durumun en geçerli sebebi nüfus farkının çok olmasıdır. Hristiyanlığın resmikabulü ile birlikte ise kilisenin etkin olduğu bir kültürel yapılanma baş göstermeye başlamıştır. Bu yapılanma da diğer Orta Çağ feodal şehirlerinde olduğu gibi, batı tarzı şehirciliği adına olumlu nüveler verilmesine neden olmuştur. 


\section{KAYNAKÇA}

Ahmetbeyoğlu A. (2010). "Bulgarları Oluşturan Boylardan Kutrigurlar ve Utigurlar”. Tarih Dergisi 51 (2010) 1-19.

Atanasov G. (2013). “'K’m v'prosa za naçaloto na B'lgarskiya srednovekoven grad (Rannosrednovekovnata krepost do S. Tsar Asen, Silistrensko ot ukrepeno selişe k'm ukrepen grad". Grad't B'lgarskite Zemi (Po arheologiçeski danni). Materiali ot Natsionalnata nauçha konferentsiya Posvetena najivota i deloto na st. n. s. Vera Antonova (2013) 205-233. Şumen.

Corbu E. (2013). "Historical Danube Influence on Early-Medieval History”. Preslav 7 (2013) 85-95.

Donçeva-Petkova L. (2000). "Ortaçağ Bulgaristan'ında Runik İşaretler ve Birleşmeler”. Çev. E. Çetin, TDAY-B (2000) 175-182.

Donçeva S. (2017). "Yuvelirnıe proizvodstvennıe kompleksı X veka vblizi Preslava. Tehnologii proizvodstva". Stratum plus: Arheologiya i kul'turnaya antropologiya (2017) 189-203.

Feher G. (1984). Bulgar Türkleri Tarihi. Ankara 1984.

Georgiyev P. (2014). "Pliska v VIII veke: Problemı i dostijeniya". Povoljskaya Arheologiya. 3/9 (2014) 193-219.

Georgiyev P. (2013). “Tuhleniyat” Preslav-realen ili v'obrajaem? (K’m problem aza areala na magapolisa Veliki Preslav)”. Preslav 7 (2013) 13-28.

Henning J. (2007). "The Metropolis of Pliska or, How Large Does an Early Medieval Settlement Have to be in Order to be Called a City?”. Post-Roman Towns, Trade and Settlement in Europe and Byzantium. Vol. 2. Byzantium, Pliska and the Balkans (2007) 209-240. Berlin-New York.

Henning J. (2012). "Pliska, Early Medieval Bulgaria and the Hungarian Raids at the Balkans: Some Archaeological Considerations”. Questiones Medii Aevi Novae 17 (2012) 1-12.

Henning J. \& Balabanov T. (2007). "Khan Omurtag’s Stone palace of AD 822: A “Modernized” Eight Century Timber Fort”. Post-Roman Towns, Trade and Settlement in Europe and Byzantium. Vol. 2. Byzantium, Pliska and the Balkans (2007) 432-440. Berlin- New York.

Henning J. \& Eyub F. (2007). "Kabiyuk: another Pliska?”. Post-Roman Towns, Trade and Settlement in Europe and Byzantium. Vol. 2. Byzantium, Pliska and the Balkans. Berlin-New York (2007) 425-432.

Hrissimov N. (2017). "Food of Plant Origin in the Life of Early Medieval Bulgarians (End of $7^{\text {th }}$-Beginning of $11^{\text {th }}$ Century)”. Studia Ceranea 7 (2017) 59-77.

Huzin F. Ş. (2006). "Velikiy gorod na Çeremşane i gorod Bulgar na Volge". F. Huzin (Otv. Red.). İstoriya Tatar s drevneyşih vremen v semi tomah tom II Voljskaya Bulgariya i velikaya step. İzd. Ruhil. Kazan (2006) 163-179.

Jireçek K. (1978). İstoriya na bilgarite. Sofya 1978.

Karatay O. (2018a). Bulgarlar Yitik Bir Türk Kavmi. İstanbul 2018.

Karatay O. (2018b). "Tuna Bulgarları”. Eds. O. Karatay \& S. Acar. Doğu Avrupa Türk Tarihi (2018) 273294. İstanbul.

Liddell H. G. \& Scott D. D. R. (1883). Greek-English Lexicon. New York 1883.

Murdzhev P. (2008). The Medieval Town in Bulgaria, Thirteenth to Fourteenth Century. Florida 2008.

Nadırova H. G. (2010). "Hazaro-Bolgarskie traditsii v gradostroitel'stve Voljsko-Kamskoy Bulgarii". Teoriya i istoriya arhitekturı,restavratsiya i rekonstruktsiya istoriko arhitekturnogo naslediy. İvestiya KazGASU 2/14 (2010) 20-31.

Ögel B. (1991). Türk Kültür Tarihine Giriş-Türklerde Ordu, Ordugah ve Otağ. Cilt VII. Ankara 1991.

Ögel B. (2014). İslamiyetten Önce Türk Kültür Tarihi. Ankara 2014.

Polnoe sobranie Russkih letopisey (1846). I. II. Lavrentiyevskaya i Troitskaya letopisi. T. 1. Sanktpeterburg 1846.

Raşeyev R. (2006). "Pervoe Bolgarskoe tsarstvo na Dunae”. Otv. Red. F. Huzin, İstoriyaTatar s drevneyşih vremen v semi tomah tom II Voljskaya Bulgariya i velikaya step. Kazan (2006) 48-59.

Simakova O. A. (2007). "Bolgarskie zemli v Srednie veka”. İstoriya yujnıh slavyan s drevneyşih vremen do 1914 g. (2007) 164. 
Smirnov A. P. (1951). Voljskie Bulgarı. Vıp. XIX. Moskova 1951.

Stancheva M. (1993). Veliki Preslav. Sofia 1993.

Şkorpil K. V. (1905). "Domaşniy vid' i promısel”". Materialı dlya Bolgarskih drevnostey. Aboba-Pliska. İzv’stiya Russkago arheologiçeskago instituta. T. 10. Sofiya (1905) 301-331.

Takacs M. (2016). "The Ninth-Century Carpathian Basin on The North-Western Edge of The First Bulgarian State: An Overwiev of Some Hypotheses and Remarks and Their Evalution”. In Bollok, Csiky and Vida, Zwischen Byzanz und der Steppe/Between Byzantium and the Steppe. Budapeşte (2016) 502518.

Topsakal İ. (2019). İdil Bulgarları ve İslamiyet. İstanbul 2019.

Uspenskiy F. İ. (1905). "İstoriko-arheologiçeskoe znaçenie Abobı i eya okrestnostey. Raskopki. Naimenovanie drevnyago poseleniya”. Materialı dlya Bolgarskih drevnostey. Aboba-Pliska 10 (1905) $1-15$.

Uspenskiy F. İ. \& Şkorpil K. V. (1905). 'Bnov' otkrıtaya nadpis' Omortaga. Stolitsı (aulı, stanovişa) drevnih’ Bolgar’”. Materialı dlya Bolgarskih drevnostey. Aboba-Pliska 10 (1905) 544-554.

Venedikoff İ. (1947). "Preslav Şehrinde Yeni Keşfedilen Proto-Bulgar Kitabesi”. Çev. F. Preyger, Belleten XI/43 (1947) 541-557.

Yücel M. U. (2007). Illk Rus Ylllıklarina Göre Türkler. Ankara 2007.

Zlatarski V. (1970). İstoriya na blgarskata dırjava prez srednite vekove. Sofya 1970.

\section{İnternet kaynakları:}

09. 08. 2019 tarihinde şu kaynaklardan alınmıştır:

http://www.kroraina.com/pliska/pl_2.html.

http://www.kroraina.com/pliska/pl_3_9.html 
